\title{
Ecosystem structure and services in eelgrass Zostera marina and rockweed Ascophyllum nodosum habitats
}

\author{
Allison L. Schmidt ${ }^{1, *}$, Marta Coll ${ }^{1,2}$, Tamara N. Romanuk ${ }^{1}$, Heike K. Lotze ${ }^{1}$ \\ ${ }^{1}$ Department of Biology, Dalhousie University, PO Box 15000, 1355 Oxford Street, Halifax, Nova Scotia B3H 4R2, Canada \\ ${ }^{2}$ Institut de Ciencies del Mar (ICM-CSIC), Passeig maritim de la Barceloneta, 37-49, 08003 Barcelona, Spain
}

\begin{abstract}
Marine vegetated habitats provide essential functions and services to ocean ecosystems and human well-being. It is unclear, however, how different habitat types compare. Using large-scale field surveys, we compared the canopy and community structure between eelgrass and rockweed beds in Atlantic Canada and assessed their nitrogen retention, carbon storage, and habitat services. We then used binary network models of predator-prey interactions to determine food-web structure and its robustness to species loss. Despite disparate 3-dimensional canopy structure, both habitats significantly enhanced overall abundance and diversity of associated flora and fauna, including several commercially important species. Significant differences occurred in the species assemblages within and between habitats and were attributed to different settlement opportunities, food availability, predation risk, and maneuverability. While eelgrass plants had higher nitrogen content, rockweed canopies maintained 8-fold greater biomass and, thus, 14 -fold greater nitrogen and 8-fold greater carbon retention per unit area. Both rockweed and eelgrass food webs showed similarities to other temperate and tropical seagrass webs, yet their robustness to the loss of most connected species including primary producers was among the lowest; underscoring their vulnerability to disturbances affecting the functionally dominant primary producers. The present study demonstrates that marine vegetation provides important habitat, nitrogen, and carbon storage services, yet the extent of these services depends on the foundation species and its architecture. Changes in canopy structure will therefore have profound effects on associated food webs and ecosystem services. Thus, as increasing human pressures on coastal ecosystems threaten the continued supply of essential functions and services, the protection of marine vegetated habitats should be a management priority.
\end{abstract}

KEY WORDS: Canopy structure - Nitrogen retention - Carbon storage - Juvenile habitat · Diversity $\cdot$ Food-web structure $\cdot$ Species extinction $\cdot$ Human impacts

Resale or republication not permitted without written consent of the publisher

\section{INTRODUCTION}

Coastal ecosystems are among the most productive, diverse, and ecologically important habitats worldwide, and generate essential services that directly and indirectly benefit human well-being (De Groot et al. 2002, Millennium Ecosystem Assessment 2005a). Around the world, coastlines are dominated by structurally complex habitats created by intertidal or submerged aquatic vegetation that provide nutrient cycling, carbon storage, nursery, and juvenile habitat for a range of ecologically and economically important species (Adam 2002, Alongi 2002, Duarte 2002, Steneck et al. 2002, Thompson et al. 2002). Despite their ecological importance, marine vegetated habitats are facing increasing anthropogenic impacts (e.g. harvesting, disturbance, pollution, climate change) leading to fragmentation, depletion, 
or localized extinction of the habitat and its dependent species (Millennium Ecosystem Assessment 2005a, Lotze et al. 2006, Waycott et al. 2009).

Marine macrophytes use carbon and nitrogen as a function of their growth and are major contributors to net oceanic primary production stored in sediments (>30\% of total ocean carbon storage; Duarte \& Cebrián 1996). However, humans have on average doubled nitrogen loading ( $\geq 5$ to 10 fold in many cases) to coastal waters around the world since preindustrial times (Millennium Ecosystem Assessment 2005a). Increased nutrient loading has been shown to change primary producer abundance and species composition (Duarte 1995) and impair the system's ability to store and cycle nutrients (Worm et al. 2000). Anthropogenic greenhouse gas emissions have also increased exponentially since 1750 resulting in a net warming effect (IPCC 2007). Increasing water temperature is predicted to change the distribution and productivity of seagrasses (Short \& Neckles 1999) and shift the composition of rocky shore Ascophyllum nodosum-dominated habitats to mixed fucoid beds (Ugarte et al. 2010). The consequences of these shifts to the nitrogen retention and carbon storage capacity of coastal habitats are unknown.

Coastal vegetated habitats also play an important role as breeding, nursery, and foraging grounds, and provide shelter for associated species (Adam 2002, Alongi 2002, Steneck et al. 2002, Thompson et al. 2002) including many commercially important fish and invertebrates (Rangeley 1994, Heck et al. 2003, Hughes et al. 2009). The depletion of many commercial fish stocks and non-recovery of others may at least partly be driven by the loss or degradation of marine vegetated habitats (Hughes et al. 2009). Determining the relative importance of different vegetated ecosystems as juvenile habitat and refuge is vital for the proper management of finfish and invertebrate fisheries that depend on these habitats.

The present study aims to assess the ecosystem structure and services of 2 common yet contrasting temperate habitats in the northwest Atlantic: seagrass and rockweed beds. Previous studies have compared specific ecosystem services (e.g. nursery habitat) between vegetated and unvegetated habitats (e.g. Perkins-Visser et al. 1996, Arrivillaga \& Baltz 1999) or among vegetated habitats for one species or taxonomic group such as fish or invertebrates (e.g. Edgar 1990, Tupper \& Boutilier 1997). Comparisons of multiple services among different habitats has been largely missing - an important knowledge gap as differences in habitat structure may affect the functions and services they provide
(Beck et al. 2001, Bologna \& Heck 2002). The objectives of the present study were to compare (1) canopy structure, nitrogen and carbon storage, (2) species abundance and diversity of associated communities, and (3) habitat usage of adults and juveniles within and between eelgrass and rockweed canopies, based on extensive field surveys. Because biodiversity is essential for ecosystem functioning and services (Millennium Ecosystem Assessment 2005b, Worm et al. 2006), we then used binary network models of predator-prey interactions to compare (4) differences in food-web structure and their robustness to simulated species loss. Together, the field surveys and food-web modeling proved a powerful approach in evaluating ecosystem structure and services in near-shore ecosystems.

\section{MATERIALS AND METHODS}

\section{Study sites}

Study sites were located along the Atlantic coast of Nova Scotia, Canada (Fig. 1a, Table 1). Here, sheltered to moderately exposed intertidal and shallow subtidal rocky shores are dominated by extensive beds of rockweeds Ascophyllum nodosum and Fucus spp., while soft-sediment habitats are generally dominated by monospecific beds of eelgrass Zostera marina. We selected 4 sites dominated by $A$. nodosum beds (interspersed Fucus vesiculosus $\leq 35 \%$ of canopy, hereafter rockweed; Fig. 1b) and 3 sites with Z. marina (hereafter eelgrass; Fig. 1c) that were sampled 16-26 September 2006, when most mobile species are abundant (Schmidt \& Scheibling 2007). During the sampling period, sea surface temperature was $17.0 \pm 2.0^{\circ} \mathrm{C}(\mathrm{SD})$ and significant wave height $1.4 \pm 0.4 \mathrm{~m}$ (data acquisition in Halifax Harbour, buoy station $44258,44^{\circ} 49^{\prime} \mathrm{N}, 63^{\circ} 39^{\prime} \mathrm{W}, 40-100 \mathrm{~km}$ from our study sites; Fisheries and Oceans Canada, Integrated Science and Data Management, http://www. meds-sdmm.dfo-mpo.gc.ca).

\section{Sampling design}

At each site, 3 transects were laid parallel to the shore inside $(>10 \mathrm{~m}$ from the vegetation-bare substrate interface), along the edge (within the bed $<1 \mathrm{~m}$ from the interface), and outside ( $>10 \mathrm{~m}$ away from any canopy-forming vegetation) of the eelgrass or rockweed bed. Transect depth at high tide ranged from 1 to $3 \mathrm{~m}$, with outside transects generally deeper 

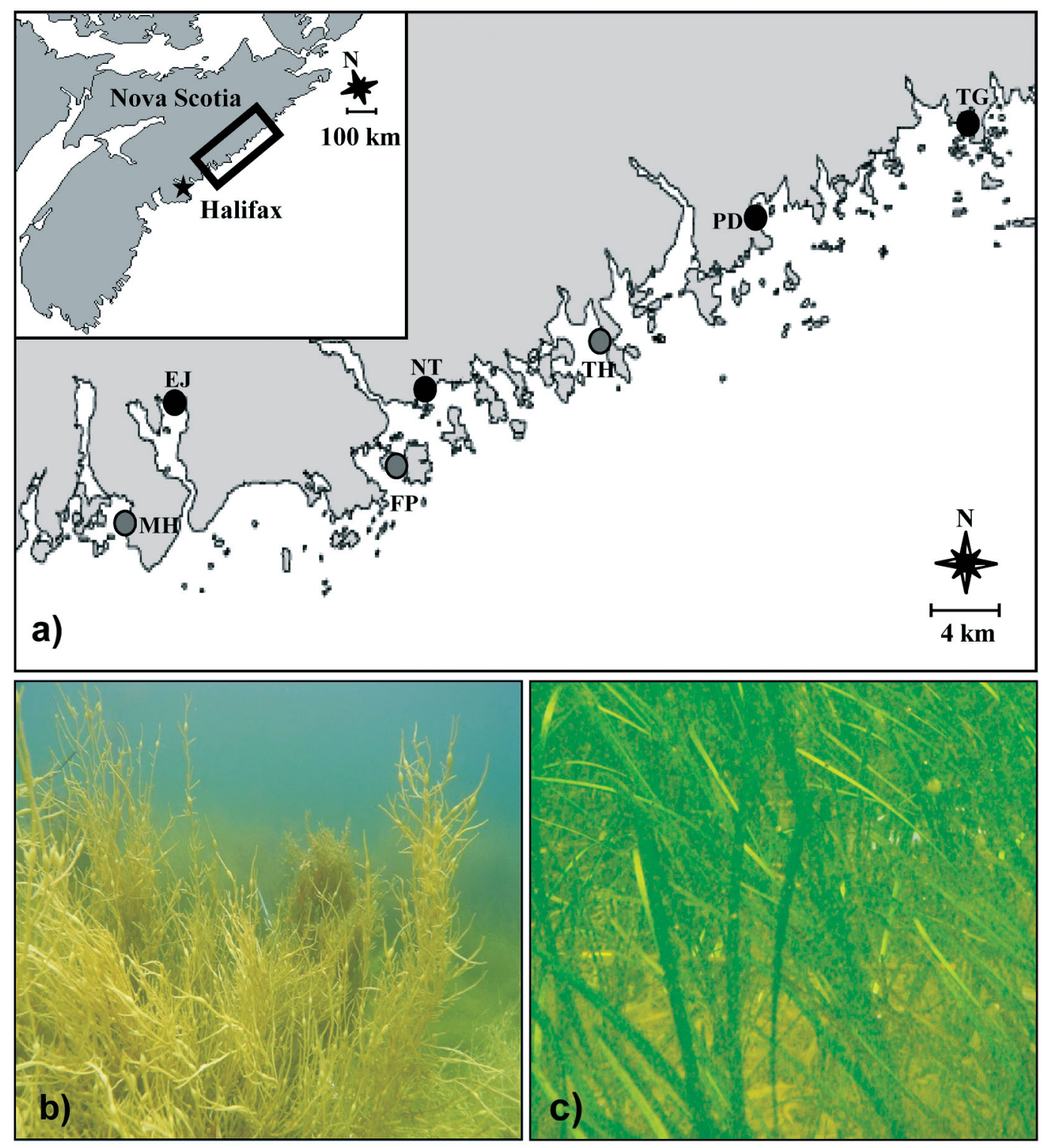

Fig. 1. (a) Study sites along the Eastern Shore of Nova Scotia, Canada, with eelgrass (O) and rockweed (๑) beds. See Table 1 for abbreviations and site characteristics. (b) Ascophyllum nodosum in East Jeddore (EJ). (c) Zostera marina in Taylor Head Provincial Park (TH)

than inside transects, but differences between the transects were $<1 \mathrm{~m}$ within each site. Highly mobile fauna were censused by the same observer swimming along transects $\left(\sim 0.08 \mathrm{~m} \mathrm{~s}^{-1}\right)$ during the dayand nighttime high tides to capture diurnal patterns in species abundance and size. We used the transect size $(50 \times 4 \mathrm{~m})$ recommended for underwater visual censuses of coral reefs (Mapstone \& Ayling 1998). Due to constraints imposed by bed size or visibility, some transects had to be shortened or narrowed (Table 1), the effect of which we analyzed (see 'Community structure and habitat services').
Canopy structure, abundance of mobile benthic species (hereafter quadrat macrofauna), and percent cover of sessile benthic and epiphytic organisms were assessed during the daytime high tide using $0.5 \times$ $0.5 \mathrm{~m}$ quadrats, covered in alternating (every $25 \mathrm{~cm}$ ) red and white electrical tape, placed at $5 \mathrm{~m}$ intervals along each transect. In the present study we consider the 'phyte' in epiphyte as referring to the host plant (eelgrass or rockweed), as recommended by Steel \& Wilson (2003). The percent cover measures of the canopy and community were estimated to the nearest $2 \%$ using the coloured tape as a guide. We consid- 
Table 1. Details of exposure (Exp), canopy location (Loc), bottom type (BT), transect length (L) and width (W) in $\mathrm{m}$, and number of quadrats (Q) per transect for each site sampled September 2006 in Nova Scotia, Canada. Sites are listed within canopy type from southwest to northeast corresponding to Fig. 1 (Rockweed $n=4$; Eelgrass $n=3$ ). Exposure included sites very sheltered (VS), sheltered (S), or moderately exposed (ME) to the predominant south-westerly winds. Canopy locations were inside (I), along the edge $(\mathrm{E})$, and outside $(\mathrm{O})$ the rockweed and seagrass beds. Bottom type included mud (M), mud and boulders (MB), cobble (C), cobble and boulders (CB), sand (S), and sand and boulders (SB). Numbers in bold indicate shorter transects (see 'Materials and methods: Sampling design')

\begin{tabular}{|c|c|c|c|c|c|c|}
\hline Site & Exp & Loc & BT & $\mathrm{L}$ & W & Q \\
\hline \multicolumn{7}{|l|}{ Rockweed } \\
\hline East Jeddore (EJ) & & I & MB & 50 & 4 & 11 \\
\hline \multirow{2}{*}{$44^{\circ} 46^{\prime} 36^{\prime \prime} \mathrm{N}, 63^{\circ} 00^{\prime} 26^{\prime \prime} \mathrm{W}$} & $\mathrm{S}$ & $\mathrm{E}$ & MB & 45 & 4 & 10 \\
\hline & & $\mathrm{O}$ & $\mathrm{M}$ & 50 & 4 & 11 \\
\hline Necum Teuch (NT) & & I & MB & 45 & 2 & 10 \\
\hline \multirow[t]{2}{*}{$44^{\circ} 57^{\prime} 07^{\prime \prime} \mathrm{N}, 62^{\circ} 10^{\prime} 99^{\prime \prime} \mathrm{W}$} & $\mathrm{S}$ & $\mathrm{E}$ & MB & 50 & 4 & 11 \\
\hline & & $\mathrm{O}$ & M & 50 & 2 & 11 \\
\hline Port Dufferin (PD) & & I & CB & 50 & 2 & 11 \\
\hline \multirow[t]{2}{*}{$44^{\circ} 54^{\prime} 73^{\prime \prime} \mathrm{N}, 62^{\circ} 23^{\prime} 76^{\prime \prime} \mathrm{W}$} & ME & $\mathrm{E}$ & $\mathrm{CB}$ & 50 & 4 & 11 \\
\hline & & $\mathrm{O}$ & $\mathrm{C}$ & 45 & 4 & 10 \\
\hline Tangier (TG) & & I & MB & 25 & 4 & 5 \\
\hline \multirow[t]{2}{*}{$44^{\circ} 47^{\prime} 74^{\prime \prime} \mathrm{N}, 62^{\circ} 41^{\prime} 06^{\prime \prime} \mathrm{W}$} & VS & E & MB & 50 & 4 & 11 \\
\hline & & $\mathrm{O}$ & M & 50 & 4 & 11 \\
\hline \multicolumn{7}{|l|}{ Eelgrass } \\
\hline \multicolumn{2}{|c|}{ Musquodoboit Harbour (MH) } & I & M & 40 & 2 & 9 \\
\hline \multirow{2}{*}{$44^{\circ} 42^{\prime} 46^{\prime \prime} \mathrm{N}, 63^{\circ} 04^{\prime} 50^{\prime \prime} \mathrm{W}$} & VS & E & M & 50 & 4 & 11 \\
\hline & & $\mathrm{O}$ & $\mathrm{M}$ & 45 & 2 & 10 \\
\hline False Passage (FP) & & I & $\mathrm{S}$ & 40 & 4 & 9 \\
\hline \multirow[t]{2}{*}{$44^{\circ} 44^{\prime} 37^{\prime \prime} \mathrm{N}, 62^{\circ} 47^{\prime} 45^{\prime \prime} \mathrm{W}$} & $\mathrm{S}$ & $\mathrm{E}$ & $\mathrm{S}$ & 50 & 4 & 11 \\
\hline & & $\mathrm{O}$ & $\mathrm{S}$ & 50 & 4 & 11 \\
\hline \multicolumn{7}{|l|}{ Taylor's Head } \\
\hline Provincial Park $(\mathrm{TH})$ & & I & SB & 30 & 2 & 6 \\
\hline \multirow[t]{2}{*}{$44^{\circ} 49^{\prime} 26^{\prime \prime} \mathrm{N}, 62^{\circ} 34^{\prime} 32^{\prime \prime} \mathrm{W}$} & ME & $\mathrm{E}$ & SB & 45 & 4 & 10 \\
\hline & & $\mathrm{O}$ & $\mathrm{S}$ & 50 & 4 & 11 \\
\hline
\end{tabular}

ered both sides of all the eelgrass blades in the quadrat as habitable space. Therefore, if both sides of all of the blades in the quadrat were covered with epiphytes, this would represent $100 \%$ cover. We first identified the species on the blades and then estimated the percent cover of each species on the collective, not each individual blade. All organisms were identified to the lowest possible taxon in the field where possible, or in the laboratory when the organisms needed further examination under a microscope. The smallest macrofauna individual sampled was 2 $\mathrm{cm}$ whereas epiphytes such as bryozoan colonies or spirorbid worms were typically $1 \mathrm{~cm}$ or less.

\section{Canopy structure and regulating services}

Our first objective was to compare the 3-dimensional canopy structure and nitrogen $(\mathrm{N})$ and carbon $(\mathrm{C})$ re- tention between the different canopy types (eelgrass, rockweed) and locations (in, edge, out). Canopy structure was assessed in each quadrat as percent canopy cover, average canopy height $(\mathrm{cm})$, and shoot (eelgrass) or holdfast (rockweed) density. The canopy cover was estimated using a $0.5 \times 0.5 \mathrm{~m}$ quadrat by the same observer hovering just above the top of the canopy. The average canopy height was estimated by placing the zero end of a measuring tape on the bottom in the middle of the quadrat and extending it upwards until it reached the average height of the plants within the quadrat. Rockweed holdfasts were counted in the $0.5 \times 0.5 \mathrm{~m}$ quadrat and eelgrass shoots in a $0.25 \times 0.25 \mathrm{~m}$ subset. Two samples of macrophyte tissue were collected on each end of the interior and edge transects for $\mathrm{C}-\mathrm{N}$ analysis. Epiphytes were scraped from tissue samples prior to drying $\left(70^{\circ} \mathrm{C}\right.$, $48 \mathrm{~h}$ ) and homogenizing, and $~ 50 \mathrm{mg}$ dry weight was analyzed with a Perkin Elmer CHN 2400 Analyser.

To estimate carbon and nitrogen storage at the canopy scale, we needed biomass estimates. We were unable to collect canopy biomass in 2006, but collected biomass together with associated percent cover, shoot density, and canopy height for eelgrass in October 2007 and rockweed in September 2008 in order to reconstruct 2006 biomass. Stepwise multiple regression determined that the best combination of variables to predict rockweed biomass were shoot density and canopy height $\left(\mathrm{R}_{\text {adj }}^{2}=0.751 ; F_{2,20}=31.1\right.$, $\mathrm{p}<0.001$ ), while for above-ground eelgrass biomass, shoot density alone was the best predictor $\left(\mathrm{R}^{2}\right.$ adj $=$ $\left.0.917 ; F_{1,11}=121.8, \mathrm{p}<0.001\right)$. The respective regression equations (rockweed biomass $=0.10 \times$ shoot density $+0.14 \times$ canopy height; eelgrass biomass $=$ $0.003 \times$ shoot density) were then used to estimate 2006 biomass based on canopy structure. Dry weight of rockweed and eelgrass was $24.6 \%( \pm 0.5 \mathrm{SE})$ and $15.5 \%( \pm 0.4 \mathrm{SE})$ of wet weight, respectively. We then used the average percent tissue carbon and nitrogen per location within each site to estimate the amount of carbon and nitrogen retained $\left(\mathrm{kg} \mathrm{m}^{-2}\right)$ in eelgrass (aboveground only) and rockweed beds.

We used linear mixed-effects models (LMM) to examine differences in canopy structure (percent cover, biomass, shoot density, canopy height), C-N tissue content and ratio, and carbon and nitrogen retention between canopy types (fixed factor with 2 levels: rockweed and eelgrass) and locations (fixed factor with 2 levels: in and edge) with sites as a random factor nested within canopy type. Canopy cover was arcsine-, and all other variables except canopy height and nitrogen retention were $\log (\mathrm{x}+1)$-transformed to satisfy assumptions of normality and vari- 
ance homogeneity. Where significant interactions were detected, we performed post-hoc comparisons using the Sidak correction. We used SPSS (version 15.0 for Windows) for all mixed-effects models.

\section{Community structure and habitat services}

Our second objective was to evaluate differences in associated species communities, including mobile and sessile flora and fauna, between canopy types and locations within canopies. We used a 3-factor multivariate permutational analysis of variance (PERMANOVA) to examine differences in biotic components (factors: Canopy, Location, Site(Canopy)) and diurnal differences in transect macrofauna (factors: Location, Site, Time of day). PERMANOVA was performed on the Bray-Curtis similarity matrix for (1) all species combined across collection methods using presence/absence and (2) separately for transect macrofauna, quadrat macrofauna, and sessile benthic and epiphytic species. Species abundance (density $\mathrm{m}^{-2}$ and percent cover) data were square-root transformed to down-weight the influence of highly abundant species and allow the rare species to influence the resemblance. We also used the zero-adjusted Bray-Curtis similarity matrix for the species abundance data to dampen the fluctuations of the metric for near-blank samples in an analogous way to the addition of a constant to the log transformation (Clarke \& Gorley 2006). Using analogues of the ANOVA estimators, PERMANOVA also estimates the components of variation for both fixed and random factors (Anderson et al. 2008a). These estimators are directly comparable and useful in determining the relative importance of different terms in the model in explaining the overall variance. Since the estimates are in terms of squared units of the Bray-Curtis similarity, the square root (SQRT-V) is taken to put them back into percent (Anderson et al. 2008a). Cluster analysis was used when PERMANOVA detected a significant diurnal, canopy, location, or interactive effect, and the SIMPER routine was used to identify those species that consistently contributed to the observed dissimilarities (dissimilarity / SD $\geq 1$; Clarke \& Warwick 2001). We tested the effects of shorter transect lengths on our results by randomly removing between 1 and 6 quadrats (depending on the original transect length) from all transects to the minimum standard of 5 quadrats (Table 1) and re-running the PERMANOVA and SIMPER analyses on all assemblage components (quadrat macrofauna, sessile benthic, and epiphytic species) collected using quadrats. We then compared the results between the original and shortened data sets (Table S1 in the supplement, available at www.int-res.com/articles/suppl/m437p051_supp. pdf). All non-parametric permutation procedures and cluster analyses were performed using PRIMER (version 6.1.11) with PERMANOVA+ (version 1.0.1, PRIMER-E, Plymouth).

LMMs were also used to test for differences in overall species richness as well as total abundance, species richness, Shannon diversity, and Pielou's evenness indices of each assemblage component (transect and quadrat macrofauna, sessile benthic, and epiphytic species) between locations (three levels: in, edge, and out) and canopy types (two levels: rockweed and eelgrass) with sites as a random factor nested within canopy. The total abundances of sessile benthic and epiphytic species were arcsinetransformed to satisfy assumptions of normality and variance homogeneity.

\section{Juvenile habitat and nursery services}

Our third objective was to test whether adult and juvenile animals use the 2 canopies in different ways. The number $\left(\mathrm{m}^{-2}\right)$ and size $(\mathrm{cm})$ of mobile fishes and decapod crustaceans (except hermit crabs) were estimated using transects for highly mobile species and quadrats for slower-moving and cryptic species. To separate juveniles from adults, we estimated individual total length of fishes and carapace width of decapods using a $15 \mathrm{~cm}$ scale bar with $1 \mathrm{~cm}$ graduations, and used published age at maturity data (Table S2 in the supplement, www.int-res.com/ articles/suppl/m437p051_supp.pdf) to group species into their respective adult and juvenile categories. Where species-specific data were not available for our region, we used the minimum reported total length at maturity for the closest region for the same or a related species (same genus or family if necessary) with a similar maximum size. Because of the overabundance of zeros, we used regression tree models to summarize the habitat and nursery services data. Tree-based models were fitted by binary recursive partitioning and used as alternatives to linear and additive regression (Clark \& Pregibon 1992). We grew a tree using the total abundance and abundance of each species observed at more than one site with life stage (adult, juvenile), canopy type (rockweed, eelgrass), and location (in, edge, out) as categorical predictors. All regression trees were grown using the statistical package R (version 2.8.0, R Foundation for Statistical Computing). 


\section{Food-web structure and functioning}

Finally, we assembled the species lists into binary presence-absence food webs to compare food-web structure between rockweed and eelgrass habitats. Species lists were compiled from field surveys and trophic information from the scientific literature for the study region (Table S3 in the supplement, www.int-res.com/articles/suppl/m437p051_supp.pdf). Food webs contained all species identified in the field including primary producers, benthic and pelagic invertebrates, and fishes. We also included marine mammals and birds that were observed in the field or are known to occur in these habitats in Nova Scotia (I. McLaren pers. comm.; Table S3). Species that shared $100 \%$ of their links with other species were aggregated into trophic groups to account for potential differences in resolution and completeness of species lists between habitats (Cohen \& Briand 1984, Dunne 2005). We used 16 properties to characterize food-web structure (Table 2, based on Dunne et al. 2004, Coll et al. 2008) that were estimated using previously developed software (Williams \& Martinez 2000, Williams et al. 2002). Visualization was done using FoodWeb3D (R. J. Williams, Pacific Ecoinformatics and Computational Ecology Lab). We then

Table 2. Food web properties for rockweed and eelgrass network models. Properties in bold were included in the MDS analysis comparing aquatic ecosystems (see Fig. 9)

\begin{tabular}{|c|c|c|c|}
\hline Food web property & Symbol & Rockweed & Eelgrass \\
\hline Species count & $\mathbf{S}$ & 60 & 51 \\
\hline Linkage density & L/S & 12.42 & 13.65 \\
\hline Connectance & $\mathbf{C}$ & 0.21 & 0.27 \\
\hline Fraction of top predators & $\% \mathbf{T}$ & 15 & 22 \\
\hline $\begin{array}{l}\text { Fraction of intermediate } \\
\text { species }\end{array}$ & $\% \mathbf{I}$ & 70 & 63 \\
\hline Fraction of basal species & $\% \mathbf{B}$ & 15 & 16 \\
\hline Fraction of herbivores & $\% \mathrm{H}$ & 7 & 6 \\
\hline $\begin{array}{l}\text { Generality - number of } \\
\text { prey items per predator }\end{array}$ & Gen & 0.93 & 0.88 \\
\hline $\begin{array}{l}\text { Vulnerability-number } \\
\text { of predators by prey }\end{array}$ & Vul & 2.05 & 2.16 \\
\hline $\begin{array}{l}\text { Fraction of species } \\
\text { involved in looping }\end{array}$ & \%Loop & 8 & 4 \\
\hline $\begin{array}{l}\text { Mean short-weighted } \\
\text { trophic level }\end{array}$ & mTL & 1.94 & 1.83 \\
\hline Maximum trophic level & $\operatorname{maxTL}$ & 3.03 & 3.00 \\
\hline $\begin{array}{l}\text { Mean number of links in } \\
\text { every possible food chain or } \\
\text { sequence of links connect- } \\
\text { ing top to basal species }\end{array}$ & Chain & 2.10 & 2.08 \\
\hline Fraction of omnivory & $\%$ Omn & 83 & 82 \\
\hline Fraction of cannibalism & $\%$ Can & 10 & 12 \\
\hline Mean trophic path length & Path & 1.97 & 1.96 \\
\hline
\end{tabular}

compared the rockweed and eelgrass food webs to 18 other published aquatic food webs from temperate and tropical systems (Dunne et al. 2004) using MDS and cluster analysis on the normalized Euclidean distance matrix of 11 properties common to all food webs (Table 2, properties in bold).

To examine whether differences in structural properties affect the robustness of each food web to species loss, we explored the effects of simulated species removals on triggering secondary extinctions (Dunne \& Williams 2009). A secondary extinction is defined as the loss of a species that occurs when a previous removal results in the loss of prey or when a cannibalistic species loses all of its prey except itself. Species loss was simulated sequentially by removing (1) the least connected species, the most connected species (2) including and (3) excluding primary producers (i.e. basal species), and (4) randomly chosen species (from 1000 random removal sequences) in each food web. We consider an ecosystem to be collapsed if all species have gone extinct.

\section{RESULTS}

\section{Canopy structure}

Canopy cover was significantly higher inside than at the edge of rockweed and eelgrass beds (Fig. 2a, LMM: $F_{1,127.9}=18.2, \mathrm{p}<0.001$ ) without differences between canopy types. Biomass of rockweed was $8 \times$ that of eelgrass (Fig. $2 b_{;} F_{1,4.88}=55.3, p=0.001$ ) with no differences between bed locations. Shoot density was $4 \times$ higher in eelgrass than rockweed (Fig. 2c; $F_{1,4.91}=9.13, \mathrm{p}=0.03$ ) and canopy height double (Fig. $2 \mathrm{~d}_{i} F_{1,5}=9.16, \mathrm{p}=0.029$ ), with eelgrass blades reaching lengths of $>1 \mathrm{~m}$. In both habitats, shoot density and canopy height were greater inside than along the edge $\left(F_{1,128.2}=4.78, \mathrm{p}=0.03 ; F_{1,127.2}=4.06\right.$, $\mathrm{p}=0.046$, respectively) with no interactions between canopy type and location.

\section{Carbon and nitrogen retention}

Tissue carbon content was similar in both canopy types (LMM: $F_{1,5.8}=1.12, \mathrm{p}=0.33$ ) and across locations (Fig. 3a; $F_{1,28.2}=1.12$, p > 0.33), while tissue nitrogen was almost double in eelgrass (Fig. 3b; $\left.F_{1,4.84}=22.03, \mathrm{p}=0.006\right)$ but similar between locations. There was a significant interaction between canopy and location $\left(F_{1,127.5}=5.56, \mathrm{p}=0.02\right)$ for car- 

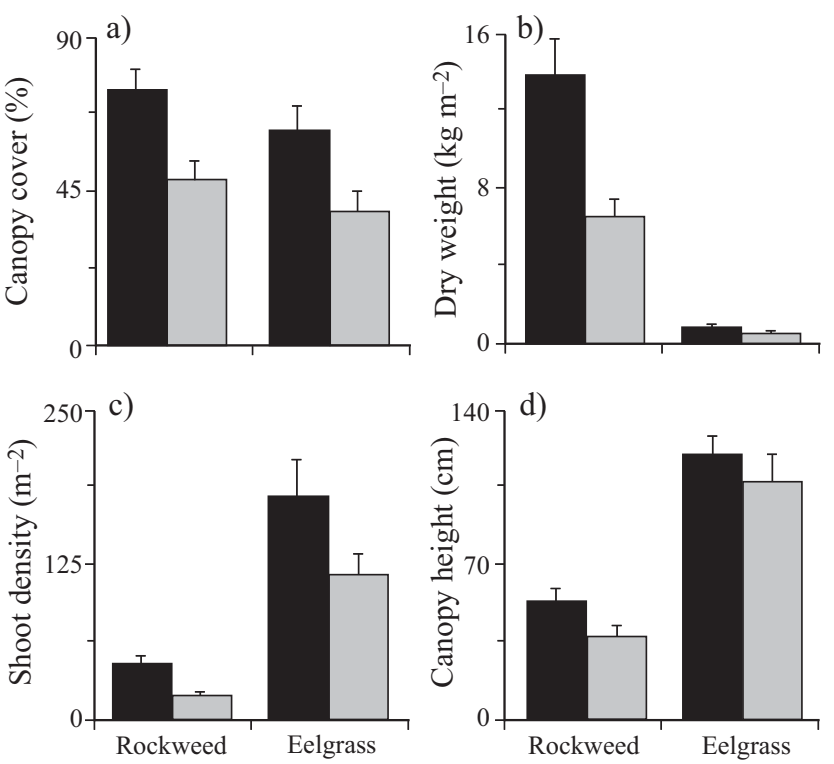

Fig. 2. Canopy structure in the interior (black bars) and along the edge (grey bars) of rockweed and eelgrass beds. (a) Percent cover, (b) dry weight (eelgrass $\times 10$ ), (c) shoot density, and (d) canopy height. Data are mean $\pm \mathrm{SE}$
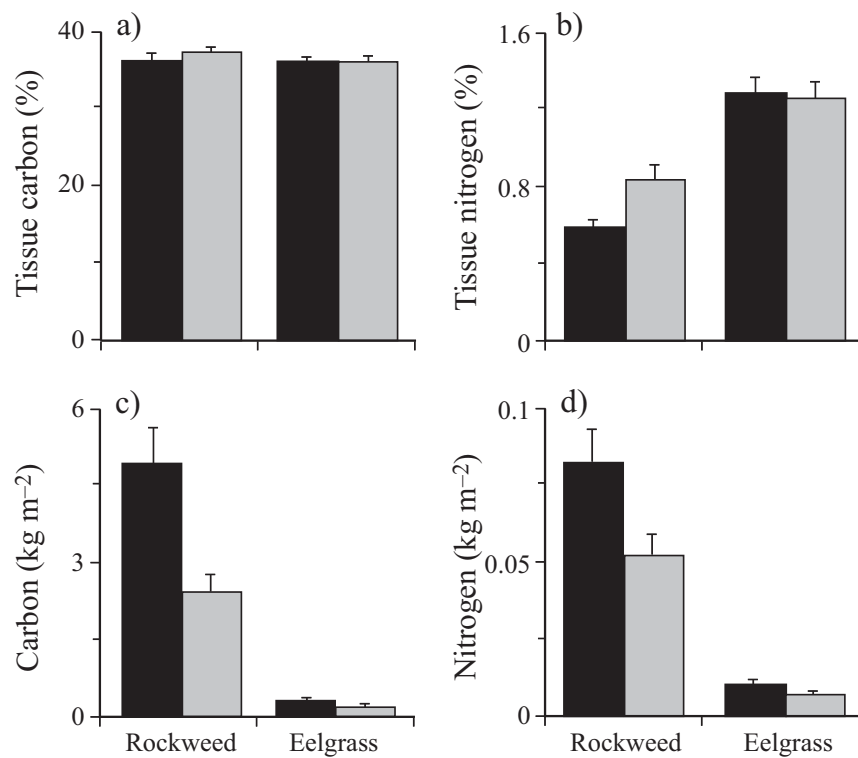

Fig. 3. Regulating services in the interior (black bars) and along the edge (grey bars) of rockweed and eelgrass beds. (a) Tissue carbon and (b) tissue nitrogen content (\% dry weight), and (c) carbon storage and (d) nitrogen retention per unit area. Data are represent mean $\pm \mathrm{SE}$

bon storage, which was on average $14 \times$ greater in rockweed than eelgrass beds (Fig. 3c; post hoc: p < 0.001). Also, carbon storage inside rockweed beds was $2 \times$ that of their edges (post hoc: $p<0.01$ ), while there was no difference within eelgrass beds (post hoc: $p=0.941$ ). Nitrogen retention was $8 \times$ greater in rockweed beds (Fig. $3 d_{i} F_{1,4.93}=42.7, p=0.001$ ) and about $1.5 \times$ greater inside both canopies than along the edge $\left(F_{1,128}=3.8, \mathrm{p}=0.054\right)$. Despite higher tissue nitrogen in eelgrass, the greater carbon storage and nitrogen retention of rockweed is related to its much higher biomass per unit area (Fig. 2b).

\section{Diurnal patterns in macrofaunal assemblage}

Deteriorating weather conditions precluded nighttime sampling in 2 eelgrass sites, thus statistical tests for diurnal differences were performed for rockweed habitats only. Multvariate 3-factor PERMANOVA (Location, Site [random], and Time of day) detected a significant difference between sites (pseudo- $F_{3,6}=$ 3.17, $\mathrm{p}=0.03$ ) and locations (pseudo- $F_{2,6}=4.16, \mathrm{p}=$ 0.007 ) but not in the time of day or any of the interactions $(\mathrm{p}>0.11)$. Nevertheless, some species were only observed at night (Homarus americanus, Gadus morhua, Microgadus tomcod in rockweed; Cancer borealis in eelgrass) or day (Pholis gunnellus in rockweed; Table S4 in the supplement, www.int-res. com/articles/suppl/m437p051_supp.pdf). Some were more frequently observed during night (e.g. Anguilla rostrata) or day (e.g. Scomber scombrus, Sygnathus fuscus, Tautogolabrus adspersus), and others had similar abundances during night and day (Gasterosteus aculeatus and Carcinus maenas in eelgrass). A few species were more abundant along habitat edges than the interior (Sygnathus fuscus, T. adspersus in rockweed). Because of unbalanced sampling of habitat types we only used daytime data hereafter.

\section{Community structure and habitat services}

Overall, 44 species/genera (excluding canopy species unless epiphytes) were identified during field surveys, 3 of which were observed only at night, yielding a daytime total of 41 taxa. Of these, 33 species were found in rockweed and 23 in eelgrass habitats (Table S5 in the supplement, www.int-res.com/ articles/suppl/m437p051_supp.pdf). Within rockweed beds, $48 \%$ of taxa were found inside and $78 \%$ along the edge, compared to $69 \%$ inside and $61 \%$ along the edge of eelgrass beds. Both eelgrass and rockweed had a similar percentage of taxa outside the canopy (35 and 39\%, respectively). We did not find mobile transect macrofauna outside canopies during the day, and no epiphytes given the lack of foundation species (Table S5). Eighteen taxa were found exclusively in rockweed and 7 in eelgrass. The 
canopy edges had the highest number of exclusive taxa (12) compared to 4 inside and 3 outside canopies.

We first evaluated whether different transect lengths had an effect on our data set. The abundance of mobile fauna in all transects was very low, highly variable, and lacked significant differences in any factor (see below). Our comparison between the original and shortened transect lengths for the quadrat macrofauna, sessile benthic, and epiphytic species (Table S1) indicated that most differences in composition and abundance were between sites and not driven by the number of quadrats used to collect the data. This was corroborated by previous studies examining the effect of transect length and width on highly mobile fishes and invertebrates (see Table S1). Together, this permitted us to use the original data for all further analyses.

Species richness of the entire assemblages (Fig. 4a) was greatest along the edge of both canopy types (LMM: $F_{2,10}=11.2, \mathrm{p}=0.003$ ) without differences
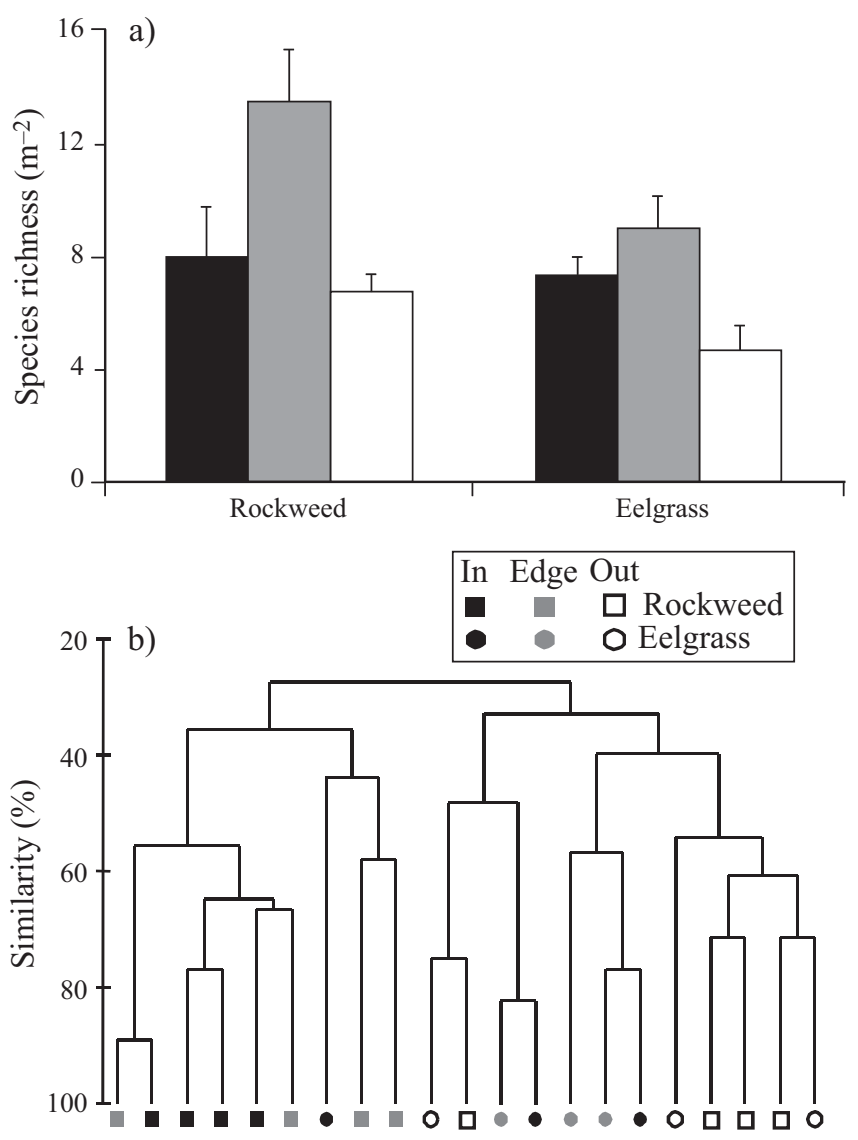

Fig. 4. Total community structure. (a) Mean $( \pm \mathrm{SE})$ species richness and (b) similarity of the communities between canopy species and locations. Both graphs are based on species presence/absence of all macrofauna, sessile benthic, and epiphytic species between canopies. There was a significant interaction between canopy and location (PERMAMOVA: pseudo- $F_{2,10}=3.1, \mathrm{p}=0.007$ ) for community composition with significant differences between locations within rockweed beds, where inside and edge locations were similar (post hoc: $p=0.16$ ) but both different from outside $(p<0.031)$. Cluster analysis revealed distinct canopy groupings and similarities between inside and edges for both rockweed and eelgrass (Fig. 4b), while assemblages outside both canopies clustered together. SIMPER analysis identified Lacuna vincta and Crangon septemspinosa as occurring more often in eelgrass, and Mytilus sp. and Chondrus crispus in rockweed (Table S5). The epiphytic invertebrates Membranipora membranacea and Spirorbis sp. and sessile benthic Semibalanus balanoides and $C$. crispus were more often inside or along the edge, whereas Pagurus sp., Pseudopleuronectes americanus and Crangon septemspinosa were more often outside.

Abundance and species richness patterns differed among different components of the assemblage (Fig. 5). The abundance of all mobile transect and quadrat macrofauna was higher inside and along the edge than outside (Fig. 5a,b), whereas sessile benthic and epiphytic species were most abundant along the edge (Fig. 5c,d). For highly mobile transect fauna (Fig. 5a), no significant differences in total abundance or community composition occurred between canopy types (LMM: $F_{1,5}=0.78, \mathrm{p}=0.79$; PERMANOVA: pseudo- $F_{1,6}=0.17, \mathrm{p}=1$, respectively) or locations within habitats $\left(F_{2,10}=1.7, \mathrm{p}=0.22\right.$; pseudo$F_{1,6}=0.18, \mathrm{p}=0.9$ ) nor was there an interaction $\left(F_{2,10}=1.5, \mathrm{p}=0.28\right.$; pseudo- $\left.F_{2,6}=0.44, \mathrm{p}=0.73\right)$, likely due to low occurrences and large variability in the data. Species richness was similar within and between canopies, but no mobile species were observed outside (LMM: $F_{2,10}=7.96, \mathrm{p}=0.009$; Fig. 5e).

For the quadrat macrofauna community, a significant interaction between location and site nested within canopy was detected in the PERMANOVA (Table 3), which was driven by significant differences in species abundance and composition between inside and edge locations in 3 of 7 sites (Table 4). The total abundance of quadrat macrofauna (Fig. 5b) inside eelgrass bed was double that inside rockweed beds, and while highest along the edge in rockweed was highest inside eelgrass beds (LMM Interaction: $F_{2,205}=6.56, \mathrm{p}=0.002 ;$ Fig. 5b). The significant effect of canopy and location on the community accounted for 23.8 and $18.8 \%$ of the variance, respectively (Table 3), which was lower than the residual (27.8\%) but higher than the variance explained by the inter- 

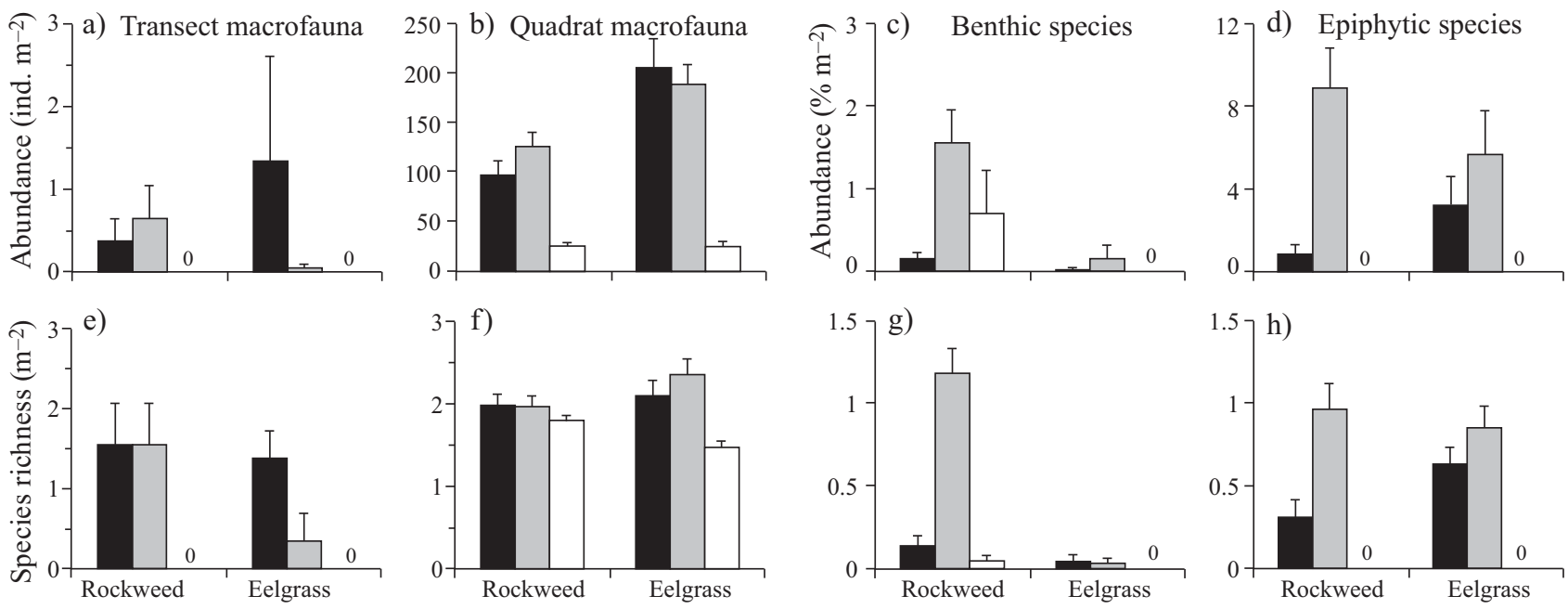

Fig. 5. Mean $( \pm \mathrm{SE})$ total abundance and species richness of mobile macrofauna surveyed using $(\mathrm{a}, \mathrm{e})$ transects and $(\mathrm{b}, \mathrm{f})$ quadrats, and sessile $(\mathrm{c}, \mathrm{g})$ benthic and $(\mathrm{d}, \mathrm{h})$ epiphytic flora and fauna surveyed using quadrats in the interior (black bars), along the edge (grey bars), and outside (white bars) of rockweed and eelgrass beds. Zero values are indicated

action Location $\times$ Site(canopy) $(18.1 \%)$. SIMPER analysis indicated that Pagurus sp., Lacuna vincta, and Crangon septemspinosa were more abundant in eelgrass, and Littorina spp. and Carcinus maenas in rockweed. Species consistently more abundant in the canopy interior included Lacuna vincta, Littorina spp., Asterias forbesii, and Carcinus maenas, whereas Crangon septemspinosa and Pagurus sp. were more abundant outside. Quadrat macrofauna richness was higher inside and along the edge (LMM: $F_{2,200.3}=$ 5.91, $\mathrm{p}=0.003)$ without differences between canopies $\left(F_{1,5.0}=0.45, \mathrm{p}=0.84\right)$ or an interaction $\left(F_{2,200.3}=\right.$ $2.66, \mathrm{p}=0.072$; Fig. 5f). Diversity was similar within and between canopies ( $p>0.260)$, yet evenness increased from inside to edge to outside $\left(F_{2,145.2}=\right.$ 2.93, $\mathrm{p}=0.057$ ).

Sessile benthic species were on average $14 \times$ more abundant in rockweed than eelgrass, and within rockweed habitats 2 to $10 \times$ more abundant along the edge than outside or inside the canopy, respectively (LMM Interaction: $F_{2,200.4}=4.08, \mathrm{p}=0.018$; Fig. $5 \mathrm{c}$ ). The significant interaction Location $\times$ Site(Canopy) for the sessile benthic community (Table 3 ) was likely driven by the low number of species (denominator of post hoc $t$-test was 0 ) in 2 eelgrass sites and significantly different assemblages found along the edge at 2 rockweed sites (Table 4). SIMPER analysis identified Chondrus crispus and Cladophora rupestris as being more abundant along the edge in rockweed. Sessile benthic species richness was significantly greater along the edge of rockweed beds compared to other locations or eelgrass (LMM Interaction: $F_{1,200.4}=31.5, \mathrm{p}<0.001$; Fig. $5 \mathrm{~g}$ ), yet this was the only location with $>1$ species.

Total epiphyte abundance was $10 \times$ greater along the edge than inside rockweed beds, while there was a more even distribution in eelgrass (LMM Interaction: $\left.F_{2,200.3}=3.0, p=0.053\right)$. The interaction Loca-

Table 3. PERMANOVA results on the effect of canopy, location, and site nested in canopy on the quadrat macrofauna, sessile benthic, and epiphytic species abundance collected using the original transect lengths (see Table S1 in the supplement, available at www.int-res.com/articles/suppl/m437p051_supp.pdf, for results using standardized shortened transects). SQRT-V are unbiased estimates of the components of variance for each of the fixed (F) and random (R) factors in the model. Negative SQRT-V values indicate that there is no evidence against the null hypothesis (Anderson et al. 2008a)

\begin{tabular}{|c|c|c|c|c|c|c|c|c|c|c|}
\hline \multirow{2}{*}{ Source } & \multirow[t]{2}{*}{ df } & \multicolumn{3}{|c|}{ Quadrat macrofauna } & \multicolumn{3}{|c|}{ Sessile benthic } & \multicolumn{3}{|c|}{ Epiphytic } \\
\hline & & Pseudo- $F$ & $\mathrm{p}$ & SQRT-V & Pseudo- $F$ & $\mathrm{p}$ & SQRT-V & Pseudo-F & $\mathrm{p}$ & SQRT-V \\
\hline Canopy (F) & 1 & 6.04 & 0.021 & 23.8 & 2.69 & 0.072 & 4.68 & 0.07 & 0.97 & -3.58 \\
\hline Location $(\mathrm{F})$ & 2 & 6.95 & 0.001 & 18.8 & 2.36 & 0.072 & 5.11 & 4.39 & 0.019 & 7.44 \\
\hline Site(Canopy) (R) & 5 & 14.62 & 0.001 & 18.9 & 6.61 & 0.001 & 6.33 & 5.25 & 0.001 & 6.18 \\
\hline Canopy × Location $(\mathrm{F})$ & 2 & 4.64 & 0.004 & 20.8 & 2.34 & 0.067 & 7.19 & 0.49 & 0.788 & -4.08 \\
\hline Site(Canopy) $\times$ Location $(\mathrm{R})$ & 10 & 5.25 & 0.001 & 18.1 & 6.23 & 0.001 & 10.5 & 4.19 & 0.001 & 9.21 \\
\hline Residual (R) & 190 & & & 27.7 & & & 14.5 & & & 16.22 \\
\hline Total & 210 & & & & & & & & & \\
\hline
\end{tabular}


Table 4. Pairwise comparisons for significant interactions listed in Table 3. Letters refer to locations within each site (see Table 1 for abbreviations); - : denominator of the post-hoc $t$-test $=0$

\begin{tabular}{|lcccccccrrr|}
\hline \multirow{2}{*}{ Canopy type } & \multirow{2}{*}{ Site } & \multicolumn{3}{c}{ Macrofauna } & \multicolumn{3}{c}{ Sessile benthic } & \multicolumn{2}{c|}{ Epiphytic } \\
& & I, E & E, O & I, O & I, E & E, O & I, O & I, E & E, O & I, O \\
\hline \multirow{2}{*}{ Rockweed } & EJ & 0.346 & 0.001 & 0.001 & 0.002 & 0.001 & 0.054 & 0.001 & 0.001 \\
& NT & 0.153 & 0.001 & 0.001 & 0.064 & 0.242 & 0.238 & 0.047 & 0.007 & 0.092 \\
& PD & 0.001 & 0.001 & 0.001 & 0.001 & 0.001 & 0.471 & 0.002 & 0.003 & 0.031 \\
& TG & 0.007 & 0.001 & 0.005 & 0.721 & 0.178 & 0.314 & - & - & - \\
Eelgrass & MH & 0.082 & 0.001 & 0.001 & - & - & - & 0.613 & 0.008 & 0.028 \\
& FP & 0.242 & 0.001 & 0.001 & - & - & - & 0.222 & 0.011 & 0.001 \\
& TH & 0.022 & 0.001 & 0.001 & 0.638 & 0.507 & 0.328 & 0.169 & 0.001 & 0.038 \\
\hline
\end{tabular}

tion $\times$ Site(Canopy) detected in the epiphytic species assemblage (Table 3) was due to $\mathrm{C}$ ) the low number of species (denominator of post hoc $t$-test was 0 ) at 2 rockweed sites and the lack of significance when comparing the inside and edge locations in eelgrass (Table 4), but overall the significant effect of location on the epiphyte assemblage explained most of the variation after the residual and interaction with site (Table 3). SIMPER analysis identified Spirorbis sp. and Membranipora membranacea as more abundant along the edge in eelgrass and Fucus vesiculosus as more abundant inside rockweed. Epiphytic species richness and diversity were greatest along the edge of canopies, and richness was on average $14 \%$ greater in eelgrass than rockweed (LMM Diversity: $F_{2,200.4}=14.0, \mathrm{p}<0.001$; Richness: Interaction, $F_{2,200.3}$ $=3.28, \mathrm{p}=0.040 ;$ Fig. 5h).

\section{Juvenile habitat and nursery services}

Overall, the abundance of adult and juvenile fishes and decapods in transects and quadrats was low and variable (Fig. 6). Transect species were found exclu-
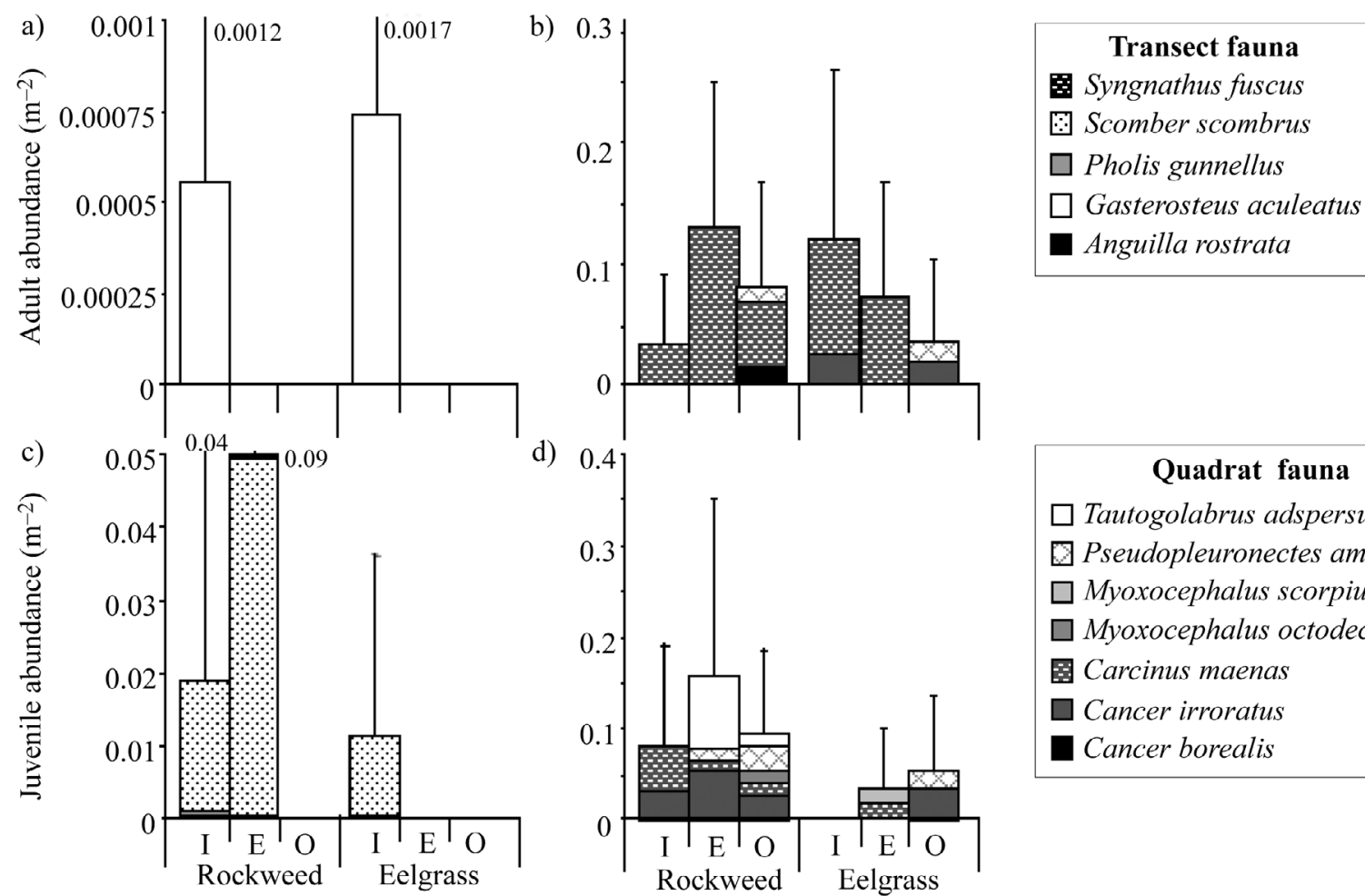

d)

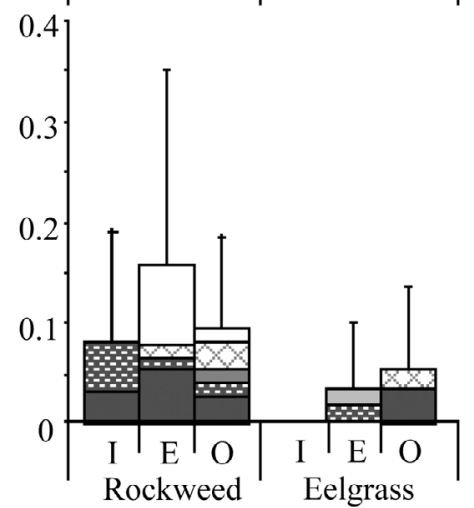

\begin{tabular}{|c|}
\hline \multicolumn{1}{|c|}{ Quadrat fauna } \\
$\square$ Tautogolabrus adspersus \\
$\square$ Pseudopleuronectes americanus \\
$\square$ Myoxocephalus scorpius \\
$\square$ Myoxocephalus octodecemspinosus \\
圈 Carcinus maenas \\
$\square$ Cancer irroratus \\
$\square$ Cancer borealis \\
\hline
\end{tabular}

Fig. 6. Mean abundance $( \pm \mathrm{SE})$ of adults and juveniles of the macrofauna species whose life stages could be distinguished based on size sampled using $(\mathrm{a}, \mathrm{c})$ transects and $(\mathrm{b}, \mathrm{d})$ quadrats in the interior $(\mathrm{I})$, along the edge $(\mathrm{E})$ and outside $(\mathrm{O})$ of rockweed and eelgrass beds. Numbers above or to the right of error bars indicate the numerical SE values. The order of the species in the legends corresponds to the vertical order in the bars 


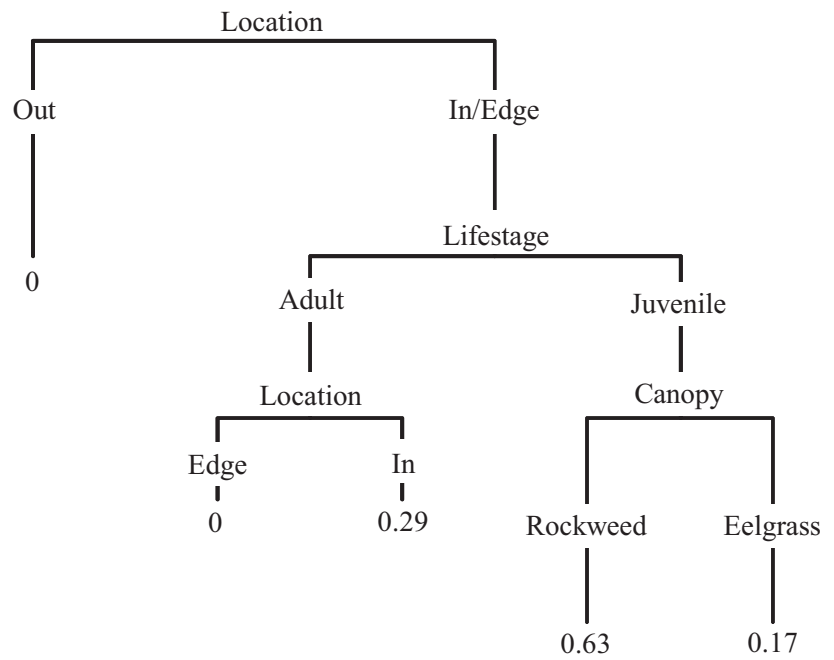

Fig. 7. Regression tree model for abundance data from transects for all species combined. Species abundance $\left(\mathrm{m}^{-2}\right)$ was the response variable and life stage (adult, juvenile), canopy type (rockweed, eelgrass), and location (in, edge, out) were categorical predictors. The numbers represent the total abundance of each branch

sively inside (adults and juveniles) or along the edge (juveniles) of rockweed and eelgrass beds (Fig. 6a,c). The regression tree indicated location within habitat as the most important splitting factor (Fig. 7). Within a canopy, life-stage further divided the tree into adult and juvenile groups, with further splits by location and canopy, respectively. Mackerel Scomber scombrus was the most abundant juvenile inside and along the edge of rockweed, and was only observed inside eelgrass (Fig. 6c). Both adult and juvenile quadrat species showed no clear patterns of habitat or location preference (Fig. 6b,d), and a regression tree did not split using total quadrat abundance. Carcinus maenas adults and juveniles were ubiquitous in rockweed, whereas in eelgrass adults occurred inside and along the edge and juveniles only along the edge (Fig. 6b,d). Tautogolabrus adspersus only occurred as juveniles along the edge and outside rockweed (Fig. 6d). Lastly, Pseudopleuronectes americanus was observed as adults and juveniles mainly outside both canopies (Fig. 6b,d).

\section{Food-web structure and functioning}

A total of 51 and 60 trophic groups were included to describe eelgrass and rockweed food webs, respectively (Fig. 8a,b, Table S3). Seven food-web properties $(\% \mathrm{~B}, \% \mathrm{H}$, maxTL, Chain, Path, \%Omn, $\%$ Can; see Table 2 for values and abbreviations) were similar across both habitats; however, some
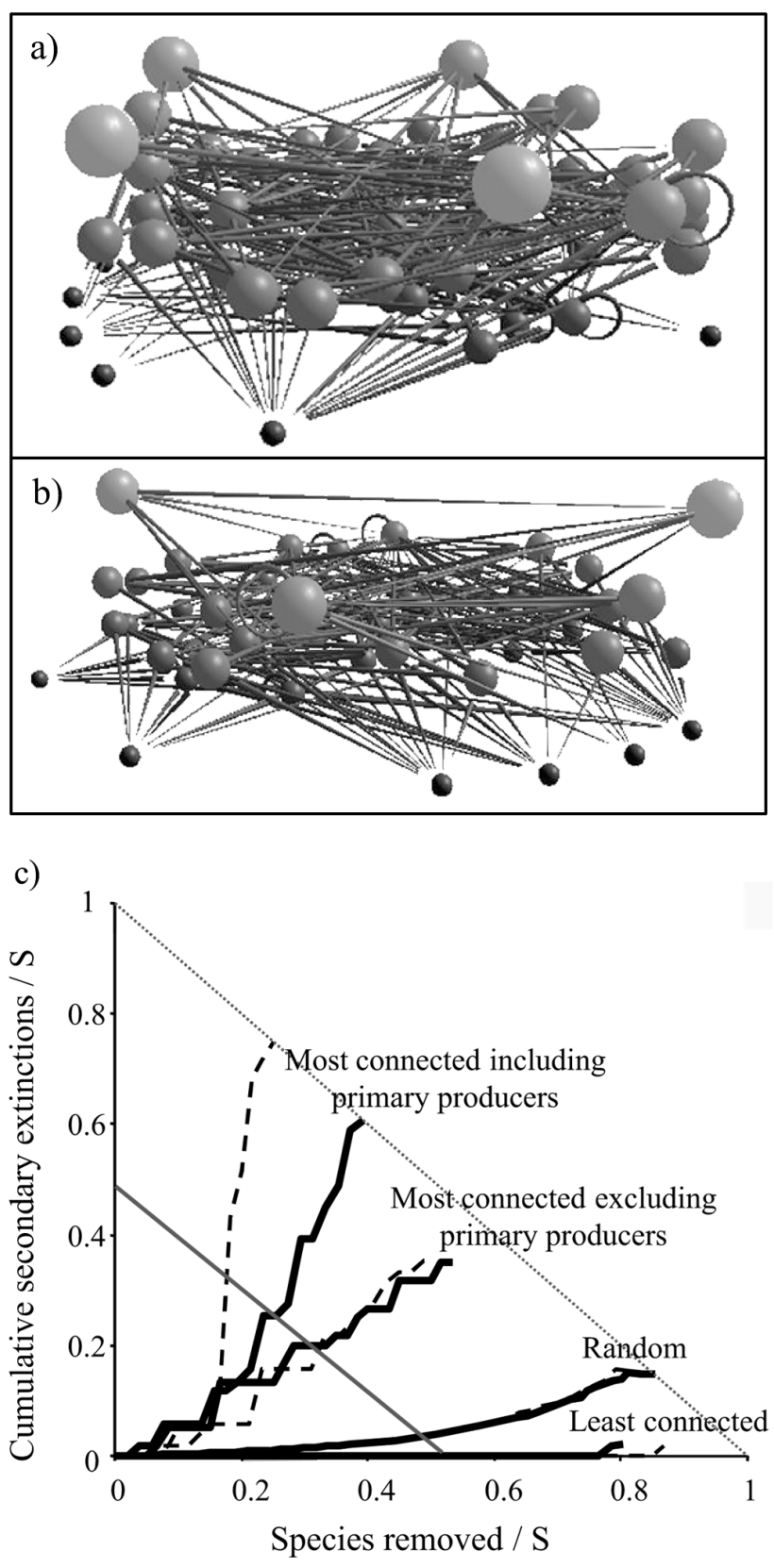

Fig. 8. Visualization of food webs in (a) rockweed and (b) eelgrass habitats, and (c) secondary extinctions in eelgrass (solid line) and rockweed (dashed line) food webs resulting from the simulated removal of species that are least connected, random, most connected excluding, and most connected including primary producers. In (a) and (b), small dark balls represent primary producers, medium grey balls represent intermediate consumers, and large light balls represent top predators. S: species count (see Table 2)

properties were higher in eelgrass $(\mathrm{C}, \mathrm{L} / \mathrm{S}, \% \mathrm{~T}$, Vul) and others in rockweed (\%I, Gen, \%Loop, $\mathrm{mTL}$ ), in agreement with differences in species assemblages between both habitats. MDS and clus- 


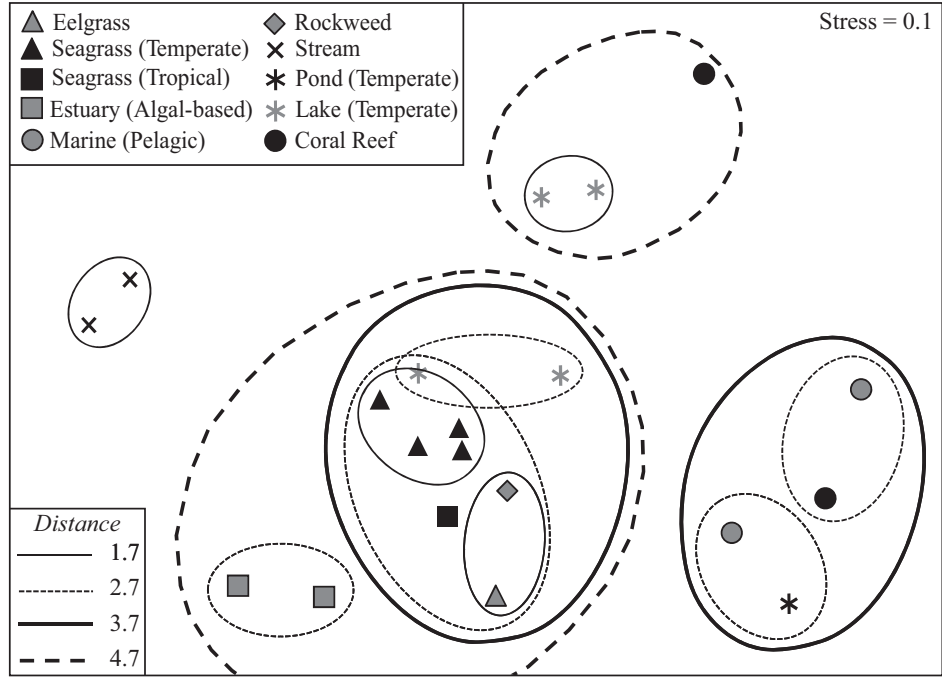

Fig. 9. Multidimensional scaling analysis overlaid with Euclidean distances from cluster analysis based on 11 food web properties (see Table 2) of 14 aquatic (Dunne et al. 2004), 4 temperate seagrass (Coll et al. 2011), and the 2 rockweed and eelgrass food webs from the present study. The marine pelagic, algal-based estuarine, and stream food webs are all from temperate systems

\section{DISCUSSION}

The ecosystem services provided by coastal vegetated habitats are essential to human well-being (Millennium Ecosystem Assessment 2005a, Hughes et al. 2009) and linked to their habitat structure and functions (Heck et al. 1995, Gotceitas et al. 1997), yet the relative importance of different vegetated systems is not well studied. Our results show that both rockweed and eelgrass habitats strongly enhance the abundance and diversity of associated species, provide juvenile and adult habitat, and retain high amounts of nitrogen and carbon. Yet there were distinct differences within and between the 2 habitats that were linked to their architecture, highlighting their unique importance for ocean ecosystems and humans.

\section{Canopy structure and storage capacity}

Most oceanic systems are dominated by phytoplankton with low biomass and high ter analysis comparing our and 18 published aquatic ecosystems grouped our rockweed and eelgrass webs within a larger cluster of temperate and tropical seagrass webs, and closer to 2 lakes and ponds and estuaries than to other freshwater and marine systems (Fig. 9).

Simulated species removals had similar consequences for rockweed and eelgrass food webs when the least connected, random, or most connected species excluding primary producers were removed (Fig. 8c). Removing the most-connected species resulted in secondary extinctions after removal of 5 to $10 \%$ of species, while removing random or least-connected species resulted in intermediate to low levels of secondary extinctions $(<14 \%)$. However, removing the most connected species including primary producers increased secondary extinctions 2-fold compared to excluding primary producers, and food webs collapsed after $25 \%$ of species removals in rockweed and $40 \%$ in eelgrass. Secondary extinctions are always high when primary producers are included in the deletion sequence; however, the rockweed food web was less robust than the eelgrass web. The robustness (proportion of primary species removals required to induce a total loss of $\geq 50 \%$ of species) to the loss of the most connected species (including primary producers) was higher in eelgrass $(24 \%)$ than in rockweed $(18 \%)$. turnover rates (<1 mo; Smith 1981). In contrast, macrophytes have the highest primary producer biomass among marine ecosystems and turnover rates of $>1$ yr. Their effect on nutrient dynamics is closely coupled with primary production, as major plant nutrients are assimilated along with carbon in approximate C:N:P ratios of 800:49:1 for macroalgae and 435:20:1 for rooted macrophytes (Pedersen et al. 2004). The substantial carbon production and nutrient uptake by marine macrophytes provides a significant carbon sink and nutrient retention through accumulation of biomass or detritus (Smith 1981, Cebrián 2002, Pedersen et al. 2004); however, we found interesting differences between eelgrass and rockweed habitats.

Most research on carbon sinks, fluxes, and sequestration has focused on net primary production ( $\mathrm{g} \mathrm{C}$ $\mathrm{m}^{-2} \mathrm{yr}^{-1}$ ) and its main pathways through ecosystems (Duarte \& Cebrián 1996, Cebrián 2002, Mateo et al. 2006), but doesn't directly take into account the existing standing stock. We estimated primary production of our rockweed and eelgrass (aboveground) beds as 1.3 and $1.6 \mathrm{~kg} \mathrm{C} \mathrm{m}^{-2} \mathrm{yr}^{-1}$, respectively, using our biomass data and primary production measures for rockweed (Vadas et al. 2004) and eelgrass (Duarte \& Chiscano 1999), and assuming a linear relationship between the 2 variables. Thus, eelgrass and rockweed may play similar roles as primary producers in coastal ecosystems. However, our rockweed had an 
order of magnitude greater standing biomass and thus greater nitrogen and carbon storage capacity. A notable omission in our storage estimates for eelgrass is its roots and rhizomes. In 2007 belowground biomass was $61 \%$ higher than aboveground biomass at our study sites (A. L. Schmidt unpubl. data); yet even after adding this, rockweed still had 5 and $9 \times$ more nitrogen and carbon per unit area, respectively.

Relatively little macroalgal and seagrass biomass is directly grazed compared to phytoplankton and microphytobenthos (Duarte \& Cebrián 1996, Worm et al. 2000, Valentine \& Duffy 2006). However, grazing may increase frond breakage (Viejo \& Åberg 2003) and enhance export and detrital pathways. Turnover rates of rockweed beds in southwestern Nova Scotia range from 3 to $15 \mathrm{yr}$ (Sharp 1987). Assuming an annual production of air bladders (Cousens 1984), our rockweed beds were $>3 \mathrm{yr}$ old, placing annual losses below $33 \%$ of standing biomass, consistent with $27 \%$ detrital losses for other rockweeds (Josselyn \& Mathieson 1980). Average losses of eelgrass can range from 3 to $25 \%$ (Josselyn \& Mathieson 1980), although these estimates considered mostly larger pieces of Zostera detritus, such as leaves or whole plants, and not smaller blade tips. Together, the low grazing and low turnover rates can lead to accumulation of biomass and detritus, and burial of carbon and nutrients in macrophyte habitats (Pedersen et al. 2004, Duarte \& Cebrián 1996). Because macrophytes invest more, relative to annual algae, into structural components and chemical defenses against grazing, decomposition of exported and detrital material is slow (Duarte \& Cebrián 1996, Moen et al. 1997, Pavia \& Toth 2000). Eelgrass has much slower decomposition rates (76 to 190 d) than rockweed (22 to $26 d_{\text {; }}$ Josselyn \& Mathieson 1980), increasing the fraction of primary production stored in sediments, which is $40 \times$ greater for seagrasses than macroalgae (Duarte \& Cebrián 1996). Thus, while rockweed has a higher storage capacity in its standing biomass, eelgrass enhances storage of primary production in sediments.

Tissue nitrogen content reflects the nutritional conditions where eelgrass and rockweed were collected, due to its link to water column nitrogen concentrations (Asare \& Harlin 1983, Duarte 1990, Burkholder et al. 1992). All our study sites, except Musquodoboit Harbour, which had a fisherman's wharf, were isolated, with $<3$ houses in close proximity and the closest small town $\geq 10 \mathrm{~km}$ away. Inorganic nitrogen concentrations near many of our sites ranged from 0.005 to $0.009 \mathrm{mg} \mathrm{l}^{-1}$ (CCME 2007). In seagrass, tissue nitrogen $<1.8 \%$ indicates strong nutrient limitation
(Duarte 1990). Our eelgrass had tissue nitrogen of 0.99 to $1.5 \%$, indicating severe nutrient limitation. Since both rockweed and eelgrass canopies occurred under the same nutrient-limiting conditions, the higher tissue nitrogen in eelgrass suggests it is more efficient at removing and retaining nitrogen than rockweed. Nevertheless, the sheer biomass of rockweed makes it an important nutrient reservoir.

\section{Habitat provision}

Rockweeds and seagrasses create distinct 3-dimensional habitats that provide settlement, refuge, and foraging opportunities for a wide range of species (Rangeley \& Kramer 1998, Heck et al. 2003, DFO 2009). In the present study, both canopies significantly enhanced abundance and diversity of associated species compared to non-vegetated habitats, as observed in other studies (Edgar 1990, Edgar \& Shaw 1995, Heck et al. 1995, Levin \& Hay 1996). However, some notable differences between habitat types occurred that can be attributed to their different architecture as well as bottom type, rocky versus soft sediment. Overall, rockweed enhanced total macrofauna abundance 5 -fold, comparable to eelgrass beds in the eastern United States (Summerson \& Peterson 1984, Heck et al. 1995) and field experiments with Sargassum filipendula (Levin \& Hay 1996). Yet at our sites, eelgrass enhanced total macrofauna abundance 9-fold, underscoring its importance in Nova Scotia.

Similar to Edgar (1990), most species in the present study showed little habitat specificity. However, those found exclusively in rockweed either need a hard substrate for attachment (Semibalanus balanoides) or feeding (Crepidula fornicata) or are typically more abundant on rocky reefs (Tautogolabrus adspersus; Tupper \& Boutilier 1997). In comparison, species exclusive to eelgrass were mainly detritivores (Nassarius trivittatus) or herbivores (Lacuna vincta) feeding on eelgrass and associated epiphytes.

Previous studies found higher faunal densities (Edgar 1990, Edgar \& Shaw 1995, Heck et al. 2003) and secondary production (Edgar et al. 1994) in seagrass beds than unvegetated areas, and at habitat edges compared to the interior (Bologna \& Heck 2002). In the present study, all mobile species were generally more abundant inside than along the edge of eelgrass, while the reverse was observed for rockweed. This may be related to the habitat structure, which is considerably less complex in eelgrass than rockweed, allowing better maneuverability. In contrast, sessile benthic and epiphytic species were more 
abundant and diverse along the edges of both habitats, likely due to the damping effect of the canopy on water flow, concentrating their larvae and propagules at the edges (Bologna \& Heck 2000, 2002).

The choice of location within and between habitat types is influenced by the abundance and distribution of prey and refuge from predation (Edgar 1990, Denno et al. 2005), which can be species- and habitat-specific. For example, one important predator in Atlantic Canada is the American lobster Homarus americanus, which supports the highest-value fishery in Canada (DFO 2008). They are typically nocturnal and may use rockweed beds as shelter during daytime (Karnofsky et al. 1989). Lobsters feed on species we found in rockweed (e.g. Carcinus maenas) and even on rockweed itself (Karnofsky et al. 1989). We observed lobsters along the edge of rockweed beds at night. Other mobile species found in eelgrass and rockweed habitats prey on sessile invertebrates (e.g. Mytilus edulis) and epiphytic algae (e.g. Polysiphonia fucoides) whose greater abundance along the edges enhances food availability for consumers.

Interestingly, juvenile and adult abundance of green crabs Carcinus maenas in rockweed habitats was inversely related, with higher adult abundance outside and along the edge and higher juvenile abundance inside the beds. Green crabs prey mostly on littorinid snails and mussels but also cannibalize smaller individuals (see Table S3 for diet references). Their increased predation efficiency along the edges and outside rockweed canopies together with other predators likely affected numbers of juvenile green crabs or forced them into the bed interior. In eelgrass, adult green crabs were highly abundant inside and along the edge, while juvenile abundance was low. The less-complex structure of eelgrass beds may enable better maneuverability of crabs and other predators inside eelgrass beds, reducing juveniles and other prey in the interior. We found complete absence of benthic juveniles and high abundance of adult predators inside eelgrass beds. These results highlight that associated species density and richness strongly depend on the presence of vegetated habitats, but different canopy structure, bottom types, and locations offer unique opportunities for settlement, refuge, and foraging.

\section{Nursery services}

Some juvenile fishes (e.g. Scomber scombrus) were found only inside or along the edge of rockweed canopies, whereas others (e.g. Tautogolabrus adper- sus) were found only along the edge or outside. Juvenile Atlantic cod Gadus morhua, once Canada's most important fishery species (Hutchings \& Reynolds 2004), were observed along the edge of rockweed at night; they use rockweed and eelgrass beds as cover from predation (Tupper \& Boutilier 1995, Laurel et al. 2003). In Nova Scotia, growth rates of juvenile cod were highest in eelgrass, but predation rates were lowest in rockweed (Tupper \& Boutilier 1995), indicating that both habitats are important for postsettlement growth and survival. Even if significant differences in juvenile abundances between structurally complex habitats are lacking (Heck et al. 2003), the population structure of species that use these habitats is likely influenced by the trade-offs between energy gained and predation risk that determine the habitat-specific growth and mortality of juveniles, as in the case of cod (Tupper \& Boutilier 1995). Increased juvenile growth and survival has been found in eelgrass and other vegetated habitats (Tupper \& Boutilier 1995, 1997, Gotceitas et al. 1997), yet it is unclear whether canopies increase the recruitment of juveniles to adult populations. Like most coastal ecosystems, however, our beds have likely been severely altered by historical and current fishing (Jackson et al. 2001, Hutchings \& Reynolds 2004, Lotze et al. 2006), masking their true role as nurseries for commercially important species.

\section{Food-web structure and robustness}

The simplicity of binary models and their ability to detect fundamental changes in food-web structure due to changes in species composition make them good tools for comparing food-web structure and robustness across ecosystems (Dunne et al. 2004). In addition, when compared to more complex models they derive similar results for common food-web properties (Coll et al. 2008). Despite strong differences in 3-dimensional canopy structure and species composition between rockweed and eelgrass communities, the overall food-web structure of the 2 habitats was more similar to each other and to other temperate and tropical seagrass webs than to other aquatic and marine webs (Dunne et al. 2004; Fig. 9). The main structural differences were a $22 \%$ lower connectance in rockweed and a $44 \%$ higher fraction of top predators in eelgrass webs.

The higher connectance in eelgrass compared to rockweed webs likely contributed to their greater robustness to the removal of the most connected species including primary producers. Our findings are 
consistent with other estuarine food webs, where an increase in connectance of $14 \%$ can lead to a $35 \%$ increase in the number of species removals required to elicit a complete collapse of the food web (Dunne et al. 2002). Secondary extinctions reached $52 \%$ in rockweed, but only $14 \%$ in eelgrass for the same level of species removal $(20 \%)$, and there was a complete food web collapse at a $15 \%$ lower species removal in rockweed than in eelgrass. These rapid declines in biodiversity are expected with the loss of functionally dominant species that are ecosystem engineers (Worm \& Duffy 2003) such as rockweed and eelgrass. This may explain why, despite high connectance, the robustness of these habitats to the removal of the most-connected species, including primary producers, is among the lowest compared to other aquatic ecosystems (Dunne et al. 2004). Thus, our results emphasize the vulnerability of eelgrass and especially rockweed communities to disturbances that can cause the loss of primary producers, especially the foundation species, and highlight the fact that the link between connectance and robustness at larger spatial scales is not straightforward and may depend on the role of the species in an ecosystem. Although the numbers of secondary extinctions appears high, $29 \%$ of crustacean and $37 \%$ of fish species disappeared after the mass mortality of seagrass beds in Florida Bay in 1987 (Matheson et al. 1999). In Australia, $49 \%$ of fauna species present inside macrophyte-dominated habitats were not found in nearby unvegetated areas (Edgar 1990). Similarly, in our study $39 \%$ and $48 \%$ of fauna species (excluding epiphytes) were not observed outside rockweed and eelgrass canopies, respectively. Guidetti (2000) found that on average $50 \%$ of fish species on algal reefs and $58 \%$ in seagrass were absent in unvegetated habitats. These numbers are comparable to the secondary extinctions rates from our simulated species removals.

\section{Human impacts on ecosystem services}

As human populations expand, so does our demand for and multiple impacts on the services that coastal ecosystems provide. Our work clearly shows that rockweed and eelgrass habitats play important roles in the coastal carbon and nitrogen cycles. Although marine vegetated habitats cover $<2 \%$ of the global ocean, they contribute to almost half of the oceanic carbon burial, playing a major role in the oceanic carbon cycle (Duarte et al. 2005). Increased nutrient loading to coastal ecosystems is shifting the primary producer assemblage from long-lived macrophytes to phytoplankton, benthic micro-, and annual macroalgae, which can decrease the ecosystems' carbon and nitrogen retention (Worm et al. 2000, Antón et al. 2011). The projected increase in nutrient loading of another 10 to $20 \%$ by 2030 (Millennium Ecosystem Assessment 2005a) will have profound repercussions on coastal ecosystems and their storage services.

Rockweed harvesting along the shores of Atlantic Canada removes large amounts of biomass (Ugarte \& Sharp 2001). Harvesting does stimulate growth and canopy regeneration with a minimum of $85 \%$ biomass recovery within a year (Ugarte et al. 2006). This may offset the carbon removed during harvest; however, long-term burial of biomass or detritus and export will likely be reduced. The removal of nitrogen will affect nitrogen fluxes within and exports to adjacent ecosystems. Trophic transfer from seagrass meadows has been shown to subsidize distant habitats such as the deep sea and even terrestrial environments (Heck et al. 2008). Many trophic transfer processes observed in seagrass habitats, such as consumption by migratory waterfowl and beach wrack by amphipods (Heck et al. 2008), are also common in rockweed-dominated habitats (Behbehani \& Croker 1982, Blinn et al. 2008), indicating that rockweed production is also subsidizing other marine and terrestrial habitats.

Nutrient loading and harvesting can further alter, reduce, fragment, or completely remove macrophyte canopies with profound effects on associated species and food webs. Both rockweed and eelgrass beds provide important habitat to a wide range of species including at least 6 commercially important species such as American lobster and Atlantic cod (Anderson et al. 2008b, DFO 2008). The effect of patchy rockweed harvesting, as in Atlantic Canada, where 15 to $50 \%$ of a patch but no more than $17 \%$ of a bed may be harvested (Ugarte et al. 2006), may create more edge-like habitat. By decreasing the clump length and biomass (Ugarte et al. 2006), harvesting effectively creates a less dense interior and could increase the total abundance and richness of species within rockweed beds. However, the uncertainty around the effects of rockweed harvesting on the associated community necessitates further research.

The low abundances of juveniles in both rockweed and eelgrass habitats may be the result of historical and current overfishing (Jackson et al. 2001, Lotze et al. 2006). The magnitude of losses of large vertebrates such as cod was enormous (Hutchings \& Reynolds 2004) and likely had profound impacts on species interactions and trophic transfer (Jackson 
et al. 2001, Coleman \& Williams 2002). Continuous fishing pressure and expansion to lower trophic species (Anderson et al. 2008b) makes it nearly impossible to truly assess the nursery function of a habitat. Another confounding factor limiting our understanding of the nursery function is the use of alternative habitats. The extent to which species can switch among habitats or locations and remain productive would help to understand the short- and long-term buffering capacity of different habitats in the event of habitat degradation or loss in an area. The accelerating loss of seagrass habitats worldwide (Orth et al. 2006, Waycott et al. 2009) and concurrent impacts on alternative habitats (Adam 2002, Alongi 2002, Steneck et al. 2002, Thompson et al. 2002, Hughes et al. 2009) could have serious implications for species using coastal vegetated habitats during any part of their life cycle. In addition, the strong response of eelgrass, and particularly rockweed, to the simulated loss of primary producers warrants further investigation, especially since regional losses of nearshore vegetation have been shown to strongly reduce the filtering and nursery services (Worm et al. 2006).

Overall, our results illustrate that rockweed and eelgrass have very different canopy structure and complexity and utilize different bottom types that support unique species assemblages. Therefore, one habitat cannot replace the other. Instead they simultaneously support coastal biodiversity and provide essential ecosystem services. The importance of eelgrass habitats in Atlantic Canada has recently been recognized by its designation as an ecologically significant species (ESS) by Fisheries and Oceans Canada (DFO 2009). Although not a tool for protection, it does officially recognize the important role of eelgrass in coastal ecosystems. On the other hand, the entire Atlantic coast of Nova Scotia and parts of the Bay of Fundy are open for rockweed harvesting (Ugarte \& Sharp 2001). The present study illustrates that the lack of protection of sufficient habitat areas may seriously affect their ecological role and the services they provide.

Acknowledgements. We thank D. Ibarra, Aquaprime Mussel Ranch, Spry Bay Campground, and Nova Scotia Department of Natural Resources for field support; J. Mills Flemming and W. Blanchard for statistical assistance; and M. Kienast for C-N analysis. This work was funded by an NSERC Discovery grant to H.K.L., a NSERC PGSD and Killam Trust Predoctoral Scholarship to A.L.S., and postdoctoral fellowships from the Spanish Ministry of Science and Technology and the European Community Marie-Curie Program through the International Outgoing Fellowships (Call: FP7-PEOPLE-2007-4-1-IOF) to M.C.

\section{LITERATURE CITED}

Adam P (2002) Saltmarshes in a time of change. Environ Conserv 29:39-61

> Alongi DM (2002) Present state and future of the world's mangrove forests. Environ Conserv 29:331-349

Anderson MJ, Gorley RN, Clarke KR (2008a) PERMANOVA+ for PRIMER: guide to software and statistical methods. PRIMER-E, Plymouth

> Anderson SC, Lotze HK, Shackell NL (2008b) Evaluating the knowledge base for expanding low-trophic-level fisheries in Atlantic Canada. Can J Fish Aquat Sci 65: 2553-2571

Antón A, Cebrián J, Heck KL, Duarte CM, Sheehan KL, Miller MEC, Foster CD (2011) Decoupled effects (positive to negative) of nutrient enrichment on ecosystem services. Ecol Appl 21:991-1009

Arrivillaga A, Baltz DM (1999) Comparison of fishes and macroinvertebrates on seagrass and bare-sand sites on Guatemala's Atlantic coast. Bull Mar Sci 65:301-319

Asare SO, Harlin MM (1983) Seasonal fluctuations in tissue nitrogen for five species of perennial macroalgae in Rhode Island Sound. J Phycol 19:254-257

Beck MW, Heck KL Jr, Able KW, Childers DL and others (2001) Identification, conservation, and management of estuarine and marine nurseries for fish and invertebrates. Bioscience 51:633-641

> Behbehani ML, Croker RA (1982) Ecology of beach wrack in northern New England with special reference to Orchestia platensis. Estuar Coast Shelf Sci 15:611-620

Blinn BM, Diamond AW, Hamilton DJ (2008) Factors affecting selection of brood-rearing habitat by common eiders (Somateria mollissima) in the Bay of Fundy, New Brunswick, Canada. Waterbirds 31:520-529

$>$ Bologna PAX, Heck KL (2000) Impact of seagrass habitat architecture on bivalve settlement. Estuaries 23:449-457

Bologna PAX, Heck KL (2002) Impact of habitat edges on density and secondary production of seagrass-associated fauna. Estuaries 25:1033-1044

Burkholder JM, Mason KM, Glasgow HB Jr (1992) Watercolumn nitrate enrichment promotes decline of eelgrass Zostera marina: evidence from seasonal mesocosm experiments. Mar Ecol Prog Ser 81:163-178

CCME (Canadian Council of Ministers of the Environment) (2007) Canadian guidance framework for the management of nutrients in nearshore marine ecosystems. Scientific Supporting Document PN 1387, Ottawa

> Cebrián J (2002) Variability and control of carbon consumption, export, and accumulation in marine communities. Limnol Oceanogr 47:11-22

Clark LA, Pregibon D (1992) Tree-based models. In: Chambers JM, Hastie TJ (eds) Statistical models in S. Wadsworth \& Brooks, Pacific Grove, CA, p 377-419

Clarke KR, Gorley RN (2006) PRIMER v6: user manual/tutorial. PRIMER-E, Plymouth

Clarke KR, Warwick RM (2001) Change in marine communities: an approach to statistical analysis and interpretation, 2nd edn. PRIMER-E, Plymouth

Cohen JE, Briand F (1984) Trophic links of community food webs. Proc Natl Acad USA 81:4105-4109

> Coleman FC, Williams SL (2002) Overexploiting marine ecosystem engineers: potential consequences for biodiversity. Trends Ecol Evol 17:40-44

Coll M, Lotze HK, Romanuk TN (2008) Structural degradation in Mediterranean Sea food webs: testing ecological 
hypotheses using stochastic and mass-balance modelling. Ecosystems 11:939-960

Coll M, Schmidt A, Romanuk T, Lotze HK (2011) Food-web structure of seagrass communities (Zostera marina) in Atlantic Canada: changes across regions and levels of eutrophication. PLoS ONE 6:1-13

Cousens R (1984) Estimation of annual production by the intertidal brown alga Ascophyllum nodosum (L.) Le Jolis. Bot Mar 27:217-227

> De Groot RS, Wilson MA, Boumans RMJ (2002) A typology for the classification, description and valuation of ecosystem functions, goods and services. Ecol Econ 41:393-408

Denno RF, Finke DL, Langellotto GA (2005) Direct and indirect effects of vegetation structure and habitat complexity on predator-prey and predator-predator interactions. In: Barbosa P, Castellanos I (eds) Ecology of predatorprey interactions. Oxford University Press, London, p 211-239

DFO (2008) Canadian fisheries statistics 2006. Fisheries and Oceans Canada, Ottawa

DFO (2009) Does eelgrass (Zostera marina) meet the criteria as an ecologically significant species? DFO Can Advis Sec Sci Advis Rep 2009/018 Fisheries and Oceans Canada, Moncton

Duarte CM (1990) Seagrass nutrient content. Mar Ecol Prog Ser 67:201-207

Duarte CM (1995) Submerged aquatic vegetation in relation to different nutrient regimes. Ophelia 41:87-112

Duarte CM (2002) The future of seagrass meadows. Environ Conserv 29:192-206

Duarte CM, Cebrián J (1996) The fate of marine autotrophic production. Limnol Oceanogr 41:1758-1766

> Duarte CM, Chiscano CL (1999) Seagrass biomass and production: a reassessment. Aquat Bot 65:159-174

> Duarte CM, Middleburg JJ, Caraco N (2005) Major role of marine vegetation on the oceanic carbon cycle. Biogeosciences $2: 1-8$

Dunne JA (2005) The network structure of food webs. In: Pascual M, Dunne JA (eds) Ecological networks: linking structure to dynamics in food webs. Oxford University Press, New York, NY, p 27-86

Dunne JA, Williams RJ (2009) Cascading extinctions and community collapse in model food webs. Philos Trans R Soc B 364:1711-1723

Dunne JA, Williams RJ, Martinez ND (2002) Network structure and biodiversity loss in food webs: robustness increases with connectance. Ecol Lett 5:558-567

> Dunne JA, Williams RJ, Martinez ND (2004) Network structure and robustness of marine food webs. Mar Ecol Prog Ser 273:291-302

> Edgar GJ (1990) The influence of plant structure on the species richness, biomass and secondary production of macrofaunal assemblages associated with Western Australian seagrass. J Exp Mar Biol Ecol 137:215-240

Edgar GJ, Shaw C (1995) The production and trophic ecology of shallow water fish assemblages in southern Australia. I. Species richness, size-structure and production of fishes in Western Port, Victoria. J Exp Mar Biol Ecol 194:53-81

> Edgar GJ, Shaw C, Watson GF, Hammond LS (1994) Comparison of species richness, size-structure and production of benthos in vegetated and unvegetated habitats in Western Port, Victoria. J Exp Mar Biol Ecol 176:201-226

Gotceitas V, Fraser S, Brown JA (1997) Use of eelgrass beds (Zostera marina) by juvenile Atlantic cod (Gadus morhua). Can J Fish Aquat Sci 54:1306-1319

> Guidetti P (2000) Differences among fish assemblages associated with nearshore Posidonia oceanic seagrass beds, rocky-algal reefs and unvegetated sand habitats in the Adriatic Sea. Estuar Coast Shelf Sci 50:515-529

Heck KL, Able KW, Roman CT, Fahay MP (1995) Composition, abundance, biomass and production of macrofauna in a New England estuary: comparison among eelgrass meadows and other nursery habitats. Estuaries 18: 379-389

Heck KL Jr, Hays G, Orth RJ (2003) Critical evaluation of the nursery role hypothesis for seagrass meadows. Mar Ecol Prog Ser 253:123-136

Heck KL, Carruthers TJB, Duarte CM, Hughes AR, Kendrick G, Orth RJ, Williams SW (2008) Trophic transfers from seagrass meadows subsidize diverse marine and terrestrial consumers. Ecosystems 11:1198-1210

Hughes AR, Williams SL, Duarte CM, Heck KL, Waycott M (2009) Associations of concern: declining seagrasses and threatened dependent species. Front Ecol Evol 7:242-246

Hutchings JA, Reynolds JD (2004) Marine fish population collapse: consequences for recovery and extinction risk. Bioscience 54:297-309

IPCC (2007) Climate change 2007: synthesis report. Fourth assessment report of the Intergovernmental Panel on Climate Change. Cambridge University Press, Cambridge

Jackson JBC, Kirby MX, Berger WH, Bjorndal KA and others (2001) Historical overfishing and the recent collapse of coastal ecosystems. Science 293:629-638

Josselyn MN, Mathieson AC (1980) Seasonal influx and decomposition of autochthonous macrophyte litter in a north temperate estuary. Hydrobiologia 71:197-208

Karnofsky EB, Atema J, Elgin RH (1989) Field observations of social behaviour, shelter use and foraging in the lobster, Homarus americanus. Biol Bull (Woods Hole) 176:239-246

> Laurel BJ, Gregory RS, Brown JA (2003) Predator distribution and habitat patch area determine predation rates on Age-0 juvenile cod Gadus spp. Mar Ecol Prog Ser 251: 245-254

> Levin PS, Hay ME (1996) Responses of temperate reef fishes to alterations in algal structure and species composition. Mar Ecol Prog Ser 134:37-47

Lotze HK, Lenihan HS, Bourque BJ, Bradbury RH and others (2006) Depletion, degradation, and recovery potential of estuaries and coastal seas. Science 312:1806-1809

Mapstone BD, Ayling AM (1998) An investigation of optimum methods and unit sizes for the visual estimation of abundances of some coral reef organisms. Great Barrier Reef Marine Park Authority, Res Publ 47 Townsville

Mateo MA, Cebrián J, Dunton K, Mutchler T (2006) Carbon flux in seagrass ecosystems. In: Larkum AWD, Orth RJ, Duarte CM (eds) Seagrasses: biology, ecology and conservation. Springer, Dordrecht, p 159-192

> Matheson RE, Sogard SM, Bjorgo KA (1999) Changes in seagrass-associated fish and crustacean communities on Florida Bay mud banks: the effects of recent ecosystem changes? Estuaries 22:534-551

Millennium Ecosystem Assessment (2005a) Ecosystems and human well-being: synthesis. Island Press, Washington, DC

Millenium Ecosystem Assessment (2005b) Ecosystems and human well-being, biodiversity synthesis. World Resource Institute, Washington, DC

Moen E, Horn S, Østgaard K (1997) Biological degradation 
of Ascophyllum nodosum. J Appl Phycol 9:347-357

Orth RJ, Carruthers TJB, Dennison WC, Duarte CM and others (2006) A global crisis for seagrass ecosystems. Bioscience 56:987-996

Pavia H, Toth GB (2000) Inducible chemical resistance to herbivory in the brown seaweed Ascophyllum nodosum. Ecology 81:3212-3225

Pedersen MF, Neilsen SL, Banta GT (2004) Interactions between vegetation and nutrient dynamics in coastal marine ecosystems: an introduction. In: Nielsen SL, Banta GT, Pedersen MF (eds) Estuarine nutrient cycling: the influence of primary producers. Aquatic Ecology Series, Kluwer Academic Publishers, Dordrecht, p 1-15

Perkins-Visser E, Wolcott TG, Wolcott DL (1996) Nursery role of seagrass beds: enhanced growth of juvenile blue crabs (Callinectes sapidus Rathburn). J Exp Mar Biol Ecol 198:155-173

Rangeley RW (1994) The effects of seaweed harvesting on fishes: a critique. Environ Biol Fishes 39:319-323

Rangeley RW, Kramer DF (1998) Density-dependent antipredator tactics and habitat selection in juvenile pollock. Ecology 79:943-952

Schmidt AL, Scheibling RE (2007) Effects of native and invasive macroalgal canopies on composition and abundance of mobile benthic macrofauna and turf-forming algae. J Exp Mar Biol Ecol 341:110-130

Sharp G (1987) Ascophyllum nodosum and its harvesting. In: Doty MS, Caddy JF, Santelices B (eds) Case studies of seven commercial seaweed resources. FAO Fisheries Tech Pap Ser No. 281, Rome, p 3-48

Short FT, Neckles HA (1999) The effects of global climate change on seagrasses. Aquat Bot 63:169-196

Smith SV (1981) Marine macrophytes as a global carbon sink. Science 211:838-840

Steel JB, Wilson JB (2003) Which is the phyte in epiphyte? Folia Geobot 38:97-99

Steneck RS, Graham M, Bourque B, Corbette D, Erlandson JM, Estes JA, Tegner M (2002) Kelp forest ecosystems, biodiversity, stability, resilience and future. Environ Conserv 29:436-459

Summerson HC, Peterson CH (1984) Role of predation in organizing benthic communities of a temperate-zone seagrass bed. Mar Ecol Prog Ser 15:63-77

Thompson RC, Crowe TP, Hawkins SJ (2002) Rocky intertidal communities: past environmental changes, present status and predictions for the next 25 years. Environ Conserv 29:168-191

Tupper M, Boutilier RG (1995) Effects of habitat on settle-

Editorial responsibility: Charles Peterson,

Morehead City, North Carolina, USA ment, growth, and postsettlement survival of Atlantic cod (Gadus morhua). Can J Fish Aquat Sci 52:1834-1841

Tupper M, Boutilier RG (1997) Effects of habitat on settlement, growth, predation risk and survival of a temperate reef fish. Mar Ecol Prog Ser 151:225-236

Ugarte RA, Sharp G (2001) A new approach to seaweed management in Eastern Canada: the case of Ascophyllum nodosum. Cah Biol Mar 42:63-70

Ugarte RA, Sharp G, Moore B (2006) Changes in the brown seaweed Ascophyllum nodosum (L.) Le Jol. plant morphology and biomass produced by cutter rake harvests in southern New Brunswick, Canada. J Appl Phycol 18: 351-359

Ugarte RA, Craigie JS, Critchley AT (2010) Fucoid flora of the rocky intertidal of the Canadian maritimes: implications for the future with rapid climate change. In: Israel A, Einav R, Seckbach J (eds) Seaweeds and their role in globally changing environments. Springer, Dordrecht, p 73-90

Vadas RL, Wright WA, Beal BF (2004) Biomass and productivity of intertidal rockweeds (Ascophyllum nodosum LeJolis) in Cobscook Bay. Northeast Nat 11:123-142

Valentine JF, Duffy JE (2006) The central role of grazing in seagrass ecology. In Larkum AWD, Orth RJ, Duarte CM (eds) Seagrasses: biology, ecology and conservation. Springer, Dordrecht, p 463-501

Viejo RM, Åberg P (2003) Temporal and spatial variation in the density of mobile epifauna and grazing damage on the seaweed Ascophyllum nodosum. Mar Biol 142: 1229-1241

Waycott M, Duarte CM, Carruthers TJB, Orth RJ and others (2009) Accelerating loss of seagrasses across the globe threatens coastal ecosystems. Proc Natl Acad Sci USA 106:12377-12381

Williams RJ, Martinez ND (2000) Simple rules yield complex food webs. Nature 404:455-456

Williams RJ, Berlow EL, Dunne JA, Barabási AL, Martinez ND (2002) Two degrees of separation in complex food webs. Proc Natl Acad Sci USA 99:12913-12916

> Worm B, Duffy JE (2003) Biodiversity, productivity and stability in real food webs. Trends Ecol Evol 18:628-632

Worm B, Lotze HK, Sommer U (2000) Coastal food web structure, carbon storage, and nitrogen retention regulated by consumer pressure and nutrient loading. Limnol Oceanogr 45:339-349

> Worm B, Barbier EB, Beaumont N, Duffy JE and others (2006) Impacts of biodiversity loss on ocean ecosystem services. Science 314:787-790

Submitted: May 4, 2010; Accepted: June 29, 2011

Proofs received from author(s): September 5, 2011 